\title{
LEX
LOCALIS
}

\section{..................... \\ Evidence in Civil Law - Slovakia}

Author:

Jana Vnuková 


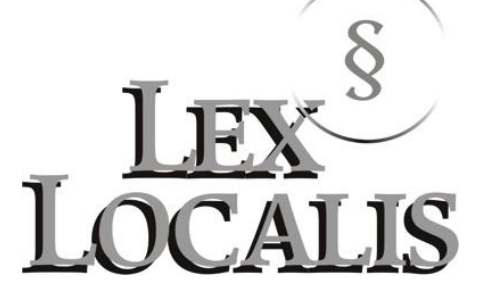




\section{(C) Institute for Local Self-Government and Public Procurement Maribor}

All rights reserved. No part of this book may be reprinted or reproduced or utilized in any form or by any electronic, mechanical, or other means, now known or hereafter invented, including photocopying and recording, or in any information storage or retriveal system, without permission in writing from the publisher.

Title: $\quad$ Evidence in Civil Law - Slovakia

Author: Jana Vnuková

First published 2015 by

Institute for Local Self-Government and Public Procurement Maribor

Grajska ulica 7, 2000 Maribor, Slovenia

www.lex-localis.press, info@lex-localis.press

Book Series: Law \& Society

Series Editor: Tomaž Keresteš

CIP - Kataložni zapis o publikaciji

Narodna in univerzitetna knjižnica, Ljubljana

$347(437.6)(0.034 .2)$

VNUKOVÁ, Jana

Evidence in civil law - Slovakia [Elektronski vir] / Jana Vnuková. - El. knjiga. - Maribor : Institute for Local Self-Government and Public Procurement, 2015. - (Lex localis) (Book series Law \& society)

Način dostopa (URL): http://books.lex-localis.press/evidenceincivillaw/slovakia

ISBN 978-961-6842-57-0 (epub)

281130752

Price: free copy

This project has been funded with support from the European Commission. This publication reflects the views only of the authors, and the Commission cannot be held responsible for any use which may be made of the information contained therein.

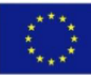

With the support of

the Civil Justice Programme

of the European Union 


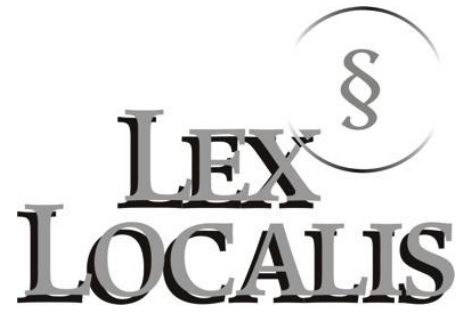

Evidence in Civil Law - Slovakia

Jana Vnuková 



\title{
Evidence in Civil Law - Slovakia
}

\author{
JANA VNUKOVÁ
}

\begin{abstract}
Like in all jurisdictions of the Member States of the European Union the Slovak civil procedure is governed by the range of principles that were developed in Europe since $19^{\text {th }}$ century. The thesis summarizes the main principles and their application by the judges when taking the evidence in the course of civil proceedings. It is evident that the observance of principles is vital not only in the drafting of legislation, but also in its implementation and claiming rights of the parties before the court. The combination of competing principles, such as free disposition principle and the officiality principle, as well as the adversarial and inquisitorial principles helps to achieve the situation in both positive law and the decision making practice of the courts, where it is possible to decide the civil cases in a fair and objective way enabling parties to use procedural tools at their disposal. The thesis further elaborates on role of principles in taking evidence at the court and it also describes the kinds and means of evidence according to the Slovak Code of Civil Procedure.
\end{abstract}

KEYWORDS: $\cdot$ civil procedure $\cdot$ principles of civil procedure $\cdot$ taking of evidence $\bullet$ kinds of evidence $\cdot$ frere assessment of evidence $\bullet$ burden of proof

CORRESPONDENCE ADDRESS: Jana Vnuková, Ministry of Foreign and European Affairs; Unit of Economic Policies at the Department of European Affairs; Hlboká cesta 2, 83336 Bratislava, Slovakia; email: jana.vnukova@mzv.sk. 


\section{Jana Vnuková}

Author Biography Jana Vnuková graduated in the Faculty of Law of the Comenious University in Bratislava, Slovakia. In 1995-2014 she has been working at the various positions in the Ministry of Justice of the Slovak Republic, including deputy director general of International and European Law Department and director of Human Rights Division. She has been working mainly in the field of private international law and European civil and family law. Currently she is working in the Slovak Ministry of Foreign and European Affairs as the head of unit of Economic Policies in the Department of European Affairs. She used to act as the chair of the Committee for the Development of Human Rights of the Council of Europe. She is the external lecturer of the Slovak Judicial Academy from its establishment in 2004, she lectures in both domestic seminars for judges and also in international fora on European law, mainly European civil law and European family law, as well as private international law. She has experience in providing consultancy from the Slovak experience from the transformation of legal order after 1989 and the accession of the country to the European Union. Her publication activities include articles in domestic and foreign legal journals on arbitration proceedings, international family law, and on private international law in Slovak legal journals. 


\section{Foreword}

General principles of civil procedure play the unique role not only in the application and interpretation of the law and its individual legal concepts, but also in pursuing the overarching goal of the civil procedure: to claim justified rights in a fair trial. The adherence to the fundamental principles in proceedings represents the guarantees of justice.

There have been tendencies in the European Union aimed at harmonising the institutes of substantive civil law with the aim to contribute to the Single Market and fundamental rights protection, however, as for the procedural law, such projects have been even more complicated. Procedural law is even more linked to the historical development and traditions of individual Member States of the EU. In order to enable cross border recovery of civil claims by facilitating cross border proceedings the principles of mutual recognition were taken as basis for further works at the level of European Union. It is often necessary to take evidence in the court of another Member States in the course of civil proceedings and that is why the Regulation (EC) no. EC No 1206/2001 of $28^{\text {th }}$ May 2001 on cooperation between the courts of the Member States in the taking of evidence in civil or commercial matters ${ }^{2}$ was adopted. It is based upon the principle that the evidence is taken by the requested court in accordance with its own legal system.

That is why knowing the basic features about kinds of evidence and ways of taking the evidence of various Member States became even more important. It helps to decrease the refusals of requests and thus contributes to the speedy and efficient cross border procedures.

General principles of the Slovak civil procedure are enshrined not only in the domestic laws, mainly in the Constitution, in the Code of Civil Procedure and in the Law on Judges, but also in the international instruments which have preference over the domestic legislation.

The thesis explains the definition and functioning of fundamental principles of civil procedure, such as principle of free disposition of parties in correlation with the officiality principle, as well as the adversarial and inquisitorial principle. Slovak civil procedure was traditionally based upon the inquisitorial principle. However, after the change of the legal system after the year 1989 several features of adversarial principle were introduced with the aim to speed the civil procedure and to reduce the workload of judges. Among other principles guiding the Slovak civil

${ }^{2}$ OJ L 174, 27.06.2001. 
procedure ranks the principle of orality, directness, public hearing and the principle of pre trial discovery which is also gaining its importance nowadays.

The thesis describes the various kinds of evidence admissible before the Slovak courts. The principle of free assessment of evidence is the guiding principle in this respect allowing the judge the large discretionary power in deciding which evidence is convincing for the court and thus will have prevailing effect for ascertaining the material truth in the respective trial. On the other hand, the free disposition of parties principle balances the procedural obligation and shifts the burden of procedural diligence towards parties.

The procedure of taking the individual kinds of evidence is also shortly outlined in the thesis as it also has impacts on the final decision of the court.

The descriptive character of the thesis has the potential to involve and introduce the reader into the overall mechanism of civil procedure and its core part - taking of evidence before the Slovak courts.

The thesis notes the harmonizing effects has the jurisprudence of the European Court of Human Rights on the main features of the civil procedure. The Court in its ad hoc decisions on concrete cases forms general principles of civil procedure with the overarching principle - right to fair trial as enshrined in article 6 of the Convention.

The new codification of civil law in the Slovakia, which in the form of three codes Civil Contentious Code, Civil Non-contentious Code and Administrative Judicial Code were adopted recently by the Parliament (in May 2015) and will enter into force as of 1 July 2016, will also reflect the need for ideal of speedy and fair protection of rights and interests of parties. While still reflecting the basic principle of civil procedural law in Slovakia - the inquisitorial principle and the principle of material truth in evidence taking, it further deepens the adversarial features aiming at increasing the procedural activity of parties of the dispute and thus aims at increasing the enforceability of law, which is one of the basic pillars of state governed by the rule law.

Knowledge of basic principles of procedure of evidence taking in the various Member States of the European Union is important due to the increased mobility and subsequent constant rise of cross border cases in the Single market and it has the potential to remove obstacles in cross border recovery of claims.

In this context I would like to highlight the importance of this project managed with the financial support from the Civil Justice/Criminal Justice Programme of the European Union by the team of Faculty of Law at the University in Maribor and coordinated by Prof. Dr. Vesna Rijavec and Prof. Dr. Tomaž Keresteš. 

Evidence in Civil Law - Slovakia

J. Vnuková

\section{Contents}

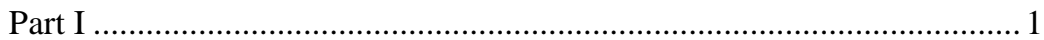

1 Fundamental Principles of Civil Procedure ……......................................... 1

$1.1 \quad$ Historical Background .......................................................................... 1

1.2 Principle of Free Disposition of the Parties and Officiality

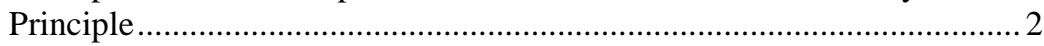

1.3 Adversarial and Inquisitorial Principle …………......................................5

1.4 Hearing of Both Parties Principle (audiatur et alter pars) Contradictory Principle ............................................................................

1.5 Principle of Orality - Right to Oral Stage of Procedure, Principle

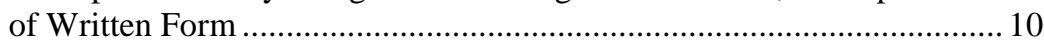

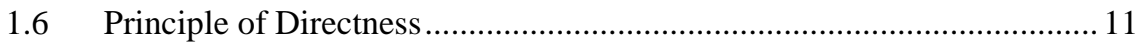

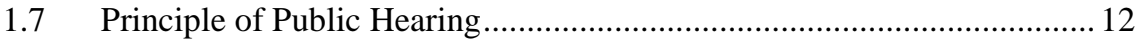

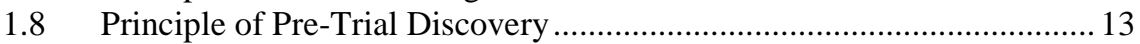

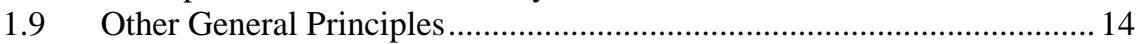

2 General Principles of Evidence Taking ………….................................. 17

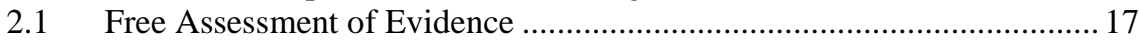

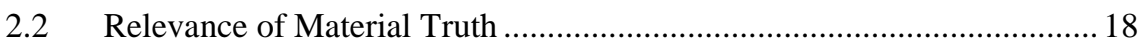

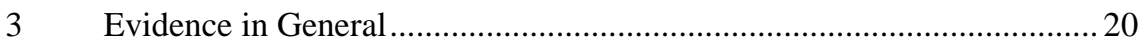

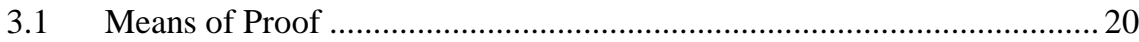

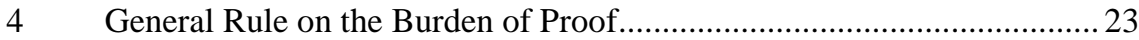

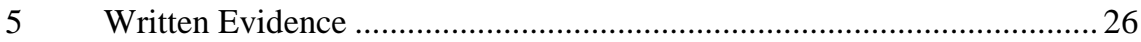

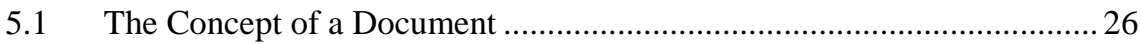

5.2 Documents for Which a Presumption of Correctness Exists ................... 27

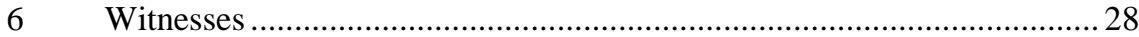

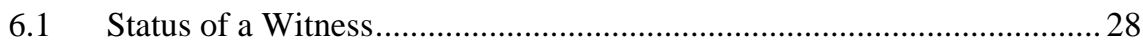

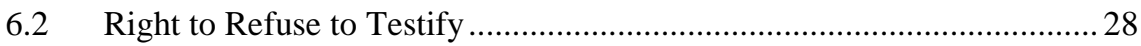

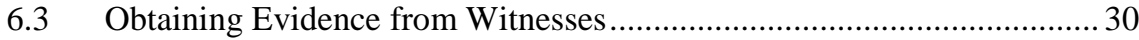

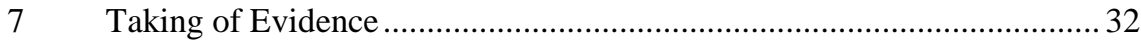

7.1 Rejection of an Application to Obtain Evidence........................................ 32

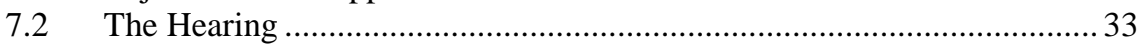

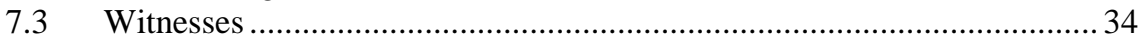

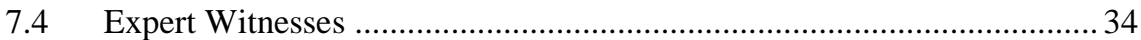

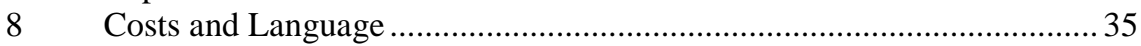

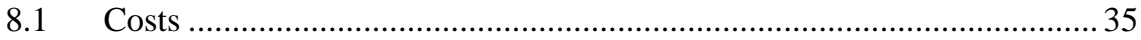

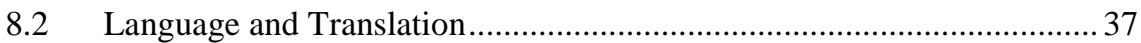

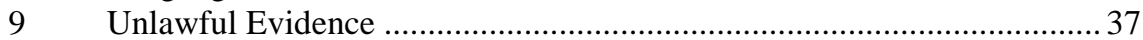

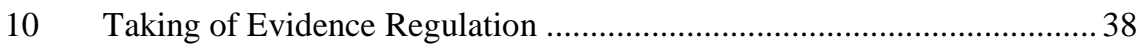

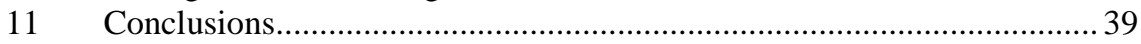

Part II - Synoptical Presentation.............................................................. 41

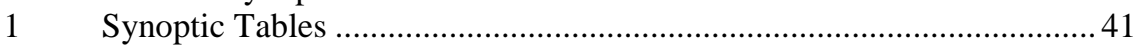


ii | Contents

1.1 Ordinary Civil Procedure Timeline According to the Slovak Legal System .................................................................................... 41

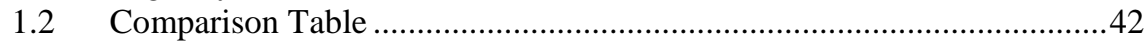

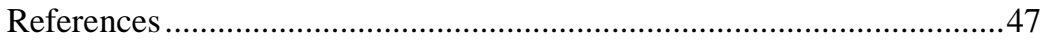


Evidence in Civil Law - Slovakia

J. Vnuková

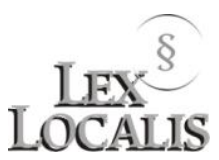

\section{Part I}

\section{Fundamental Principles of Civil Procedure}

\subsection{Historical Background}

The guiding principles of Slovak civil procedural law steam from the fact, that the Slovak civil law is based on the French Code Civile of 1804 and Austrian Algemeines Burgerliches Gesetzbuch - ABGB of 1811 and thus ranks among the continental law family. It is interesting to note in this context that the Slovak civil was also influenced also by the Hungarian customary law, not only through its recodification in 1514 by Stefan Verboczy in so called Tripartitum ${ }^{3}$, but also in the first half of $20^{\text {th }}$ century. Until 1950 when both the new Civil Code and Code of Civil Procedure were adopted, in the Czech part of the Czechoslovak Republic the ABGB and in the Slovak part the Hungarian customary law applied.

The Code of Civil Procedure of 1950 (zákon o konaní v občianskych právnych veciach) integrated all kinds of proceedings, contentious and non-contentious into one code. This was caused by the limitation of the influence of adversarial principle of procedural law and its substitution by the principle of material truth. In the communist regime the court proceedings was supposed to be not adversarial (contradictory), but both parties were to pursue the common goal of finding the material truth.

After the fall of communist regime in 1989 the transformation of the civil law into the conditions of free market economy started and as regards the civil procedural law, it is interesting to note, that the adversarial principle is being strengthened. The reason for this is the increased overload of courts and the need to strengthen the procedural autonomy of parties with the aim to reduce the burden on the side of judges and higher court officials. The answers to the questionnaire, which represents the basis for the present thesis, were based on the current law - the Code of Civil Procedure (Občiansky súdny poriadok) of 1963, which is still in force, although with more than 80 amendments.

Recently - in May 21, 2015 the Parliament adopted the package of new codes, which was commonly named as "recodification of civil procedural law". The package is composed of three codes: the Civil Contentious Code (Civilný sporový poriadok), the

\footnotetext{
${ }^{3}$ It was written in Latin language with the title: Tripartitum opus iuris consuetudinarii inclyti Regni Hungariae partiumque adnexarum.
} 
Civil Non-contentious Code (Civilný mimorsporový poriadok) and Administrative Judicial Code (Správny súdny poriadok). By this formal distinction the legislator aims at differentiation of three basic kinds of proceedings, which were formally integrated for 65 years in the Code of Civil Procedure. Especially in case of contentious proceedings, the new Civil Contentious Code aims at strengthening the principle of concentration of proceedings and increasing the elements of adversarial principle. The aim is to reduce the burden on the side of courts which based on the concept of "active judge" have to be active even if the parties did not cooperate, in order to find out the material truth in the given dispute. The all three codes will enter into force as of July 1, 2016 thus allowing for legis vacatio period of more than one year. Having in mind that this new legal regulation will be applied by the courts soon, the present thesis takes it into account and includes the solutions based especially on the Civil Contentious Code which is lex generalis in relation to the Civil Non-contentious Code.

\subsection{Principle of Free Disposition of the Parties and Officiality Principle}

In Slovakia both free disposition of the parties principle (“dispozičná zásada", which is literary translated into English as "disposition principle") and officiality principle ("zásada oficiality") apply. The free disposition principle is one of the most inherent principles to the Slovak civil procedure. It is the expression of the "narrow functional relationship between private substantive law and public civil procedural law. The aim of civil procedure is that it serves the substantive law, it provides protection to the subjective private law",

The free disposition of the parties principle is enshrined mainly in the possibility of the parties to file the civil case within the court, as everyone has the right to ask for remedy if his/her right is violated or endangered. This right includes the filing the action, its revocation, its amendments, concluding the settlement with counterparty, filing the appeal, filing the proposal for enforcement, etc. The Slovak Constitutional Court has defined the free disposition of the parties principle in its case law $^{5}$ as the civil procedural expression of the constitutional right for parties' autonomy and "it corresponds to the procedural act, containing the right of the party of the proceedings to dispose willingly with both substantive and procedural rights in the civil proceedings. The real danger of infringement of this constitutional right results also from the fact that other subject would be in a position to compel the party of the proceedings to act in the way not corresponding to his/her will. It is the eminent right of the party to decide what procedural material will s/he submit to the court...".

The central element in applying the disposition principle is the action (actio, petition) as a tool to claim any right of civil nature. The court shall not interfere with the filing of the action in any way, thus if the petition is not clear or incomplete, the court invites the party to amend or correct it ${ }^{6}$. In case the petition is not amended nor corrected, the court

\footnotetext{
${ }^{4}$ MACUR, J.: Default judgment under $§ 114 b$ of the CCP. In: Bulletin of Advocacy, 2/2002, p. 29.

${ }^{5}$ Finding of the Constitutional Court of the Slovak Republic no. 43/95.

${ }^{6}$ Article 43 of the Code of Civil Procedure.
} 
shall not take it into account, because the disposition principle means that the court cannot order the status, which was not wished by the parties. On the other hand, the fact that the court cannot interfere with the petition is balanced with the low level of formal requirements applied to the petition, as the court according to article 41 par. 2 of the Civil Procedural Code considers as decisive article 43 of the Code of Civil Procedure the content of the petition, and not its form. According to the Constitutional Court " ${ }^{7}$ "Too formal requirements in examining the acts of parties to the civil proceedings and excessive pressure on amending such requirements to the procedural acts of the parties, which are not based in the law, are beyond the law or do not have the fundamental meaning for the protection of legality, and thus are not in accordance with the constitutional principles of fair trial. The interpretation and use of article 43 of the Code of Civil Procedure has to respect in its entirety the fundamental right of parties for their judicial protection ${ }^{8}$ under the Constitution: "The interpretation and use of this provision cannot limit the fundamental right for judicial protection without legal grounds.",

Before the petition is filed, the action is entirely within the hands of party to the proceedings, after the proceedings has commenced, the proposal/action can only be amended with the consent of the court. The court decides by its resolution. The consent of the defendant is not needed. The exemption from the wilful disposition of the parties with the petition are cases when the proceedings can be initiated ex officio, i.e. upon the own motion of the court, which are stipulated in the Code of Civil Procedure ${ }^{10}$ : custody of minors, admissibility of taking over or detention of person in health facility, proceedings on legal capacity, custody matters, proceedings on declaration of a person as deceased, succession proceedings, and in some other situations taxatively stipulated by the law. The petition cannot be revoked in such cases by the parties.

The civil cases are adjudicated on the basis of article 46 par. 1 of the Slovak Constitution ("Everyone may claim by the established legal procedure his right to an independent and impartial court hearing and, in cases designated by law, to another body of the Slovak Republic" and article 142 par. 1 ("The courts shall rule on civil and criminal matters and also review the legitimacy of decisions made by bodies of public administration and legality of decisions, measures or other actions of bodies of public authority, if laid down by a law."). The principles of civil judicial procedure is laid down by the Code of Civil Procedure ("občiansky súdny poriadok") ${ }^{11}$, including the free disposition of parties principle.

The principle Iudex ne eat ultra petita partium applies in litigations. However, it does not apply absolutely, as the court can go beyond the proposals ${ }^{12}$ of litigants and to award more than requested, if the proceedings could be commenced ex offo or if the

\footnotetext{
${ }^{7}$ Finding of the Constitutional Court no. IV.ÚS 1/02.

${ }^{8}$ Article 46 par. 1 of the Slovak Constitution.

${ }^{9}$ Award of the Slovak Constitutional Court no. IV. ÚS 1/02 of 26.9.2002.

${ }^{10}$ Article 81 of the CCP.

${ }^{11}$ The law no. 99/1963 Coll. as amended.

${ }^{12}$ Under article 153 of the CCP.
} 
legal provision stipulates directly the way of settlement of certain legal relationship between the parties.

The principle of free disposition of the parties is one of the most characteristic principles immanent to the Slovak civil procedure. It is anchored in the Constitution ${ }^{13}$ ("Everyone may do what is not prohibited by law...") and stipulated in the Civil Code ${ }^{14}$ ("Everyone can seek the protection against infringement or menace of his/her right before the competent authority. Such authority is the court, unless the law stipulates otherwise."). The Code of Civil Procedure stipulates that "Everyone has the right to seek protection of his/her rights before the court." 15 . The practical enforcement of this right is realized by the procedural acts influencing the commencement, course and finalisation of the proceedings. According to the Constitutional Court ${ }^{16}$ the disposition principle corresponds to the civil expression of constitutional right of autonomy of parties enshrined in "procedural act corresponding with the right of party of civil proceedings to free disposition with his/her substantive and procedural rights in civil proceedings. Real menace of infringement of this constitutional right steams also from the fact, that other subject could be in a position to force the party to act in a way, which is contrary to his/her will. It is the right exclusively immanent to the party to decide what procedural material will s/he submit to the court." The central notion in applying the disposition principle is the action as the general mean to enforce any right of civil law nature.

The court is not bound absolutely by the action of party. The court can exceed the proposal of participants and to adjudicate more than was asked for by the action, if the proceedings could be commenced ex offo or if the legal provision stipulates directly the way of settlement of certain legal relationship between the parties.

The disposition principle means that parties can propose new evidence in essence throughout the whole proceedings until the decision of the court is issued about the finalisation of taking of evidence or until the decision in the matter is taken by the court (if the matter is decided without oral hearing). The court waits for the parties to propose all their evidence and subsequently declares formally that the stage of presenting the evidence is closed. The parties are aware that they have to present the evidence until that stage, otherwise the court decides on the basis of the evidence presented so far.

It is the right of the court to decide what evidence submitted by the parties will be taken. ${ }^{17}$ The court can also in exceptional cases take evidence other than proposed by the parties, if it considers necessary for the decision in the matter. In proceedings which could be commenced ex offo as well as in other proceedings (proceedings to allow to conclude marriage, to determine and deny paternity, about feasibility of adoption, cases

\footnotetext{
${ }^{13}$ Article 2 par. 3 of the Slovak Constitution.

${ }^{14}$ Article 4 of the CCP.

${ }^{15}$ Article 3 of the CCP.

${ }^{16}$ Award of the Constitutional Court no. PL ÚS 43/95.

${ }^{17}$ Article 118 par. 2 of the CCP.
} 
related to commercial register) the court is obliged to take other evidence necessary to ascertain the facts of the case, even if parties do not propose such evidence ${ }^{18}$.

The new Civil Contentious Code upholds the free disposition principle as one of the basic principles in its introductory part called "Basic Principles" 19 which governs the contentious proceedings.

\subsection{Adversarial and Inquisitorial Principle}

The adversarial principle is called the principle of contradiction (as derived from latin contra dicere) and ranks among the general principles of civil procedure, although it is not specifically stipulated in the Constitution nor in the Civil Procedure Code. The adversarial principle means that each parties to the dispute has the possibility to comment the claims of other party and the right to have his/her arguments heard ${ }^{20}$. It also means that the judge cannot decide the case on the basis of what have been ascertained out of proceedings ${ }^{21}$.

The inquisitorial principle applies in non-contentious proceedings, where the court is obliged ex offo and disregarding from the parties of the case to ascertain the facts of the cases in exhaustive manner. The court has to collect the evidence by its own initiative and without waiting for the evidence presented from the parties. Of course, parties can submit the evidence and the account is taken thereof by the court.

The adversarial principle is not explicitly defined in the Slovak legal system. However, from this principle follows, that it is essential for the civil proceedings, that "the party of the case shall have the possibility to consider, if and to what extent the written statement of the defendant is relevant from the legal point of view, if it contains such factual and legal reasons, which have to be addressed or expressed to; irrespectively from the real effect of these on the decision of the court.."22

However, the application of the adversarial principle is not unlimited, especially in cases, where this principle can be in contradiction with the necessity to ascertain the facts of the case.

According to the Constitutional Court ${ }^{23}$ the adversarial principle is infringed in cases, where one of the parties is denied of the possibility to comment the content and authenticity of submissions related to the facts of the case.

\footnotetext{
${ }_{18}^{18}$ Article 120 par. 2 of the CCP.

${ }^{19}$ Article 7: "Court proceedings is commenced as a principle upon the application of the party to the proceedings, and the subject of the proceedings is determined by the parties to the dispute by the procedure as stipulated by the law."

${ }^{20}$ REPÍK, B.: Human rights in court proceedings. MANZ Bratislava, 1999, p. 161.

${ }^{21}$ MACUR, J.: The Importance of statements in compliance of both parties for ascertaining the facts of the case in civil proceedings. In: Legal Horizon 2/1997, p. 49.

${ }_{22}$ Award of the Constitutional Court II. ÚS 168/2012-44.

${ }^{23}$ Award of the Constitutional Court I. ÚS 49/01.
} 
The inquisitorial principle is neither explicitly defined and it applies mostly, although not exclusively (both parties have the possibility to comment all circumstances and evidence submitted by the opposite party) in non-contentious proceedings, where the court is obliged to take all evidence necessary to ascertain the facts of the case even if the parties did not proposed them ${ }^{24}$. Non contentious proceedings include proceedings to allow to conclude marriage, to determine and deny paternity, about feasibility of adoption, cases related to commercial register, cases related to some issues concerning companies and cooperatives.

The court can in exceptional cases take evidence in contentions proceedings other than proposed by the parties, if they are necessary in order to decide the matter ${ }^{25}$.

In non-contentious proceedings the court is obliged to take all evidence necessary on its own motion, even if it was not proposed by the parties.

The judge is the "guide" who directs the whole proceedings from the beginning, as the court has also the extensive obligation to instruct the parties in order to assist the smooth course of the proceedings, including the obligation to ask the applicant to correct/amend the action, etc.

The judge ${ }^{26}$ (or presiding judge if the case is decided by the panel of judges) only informs the parties of the preparation of the hearing in fact means that the judge summarizes the dispute, summarizes the affirmations of both parties and outlines the course of taking of evidence, but s/he does not prepare the list of references as such.

The judge informs the parties about the results of the preparation of the proceedings after the hearing is open and the parties address the court.

The party can suggest the new evidence until the decision of the court about the closure of evidence is taken, i.e. there is the possibility to submit the evidence throughout the whole proceedings.

The new Civil Contentious Code strengthens the adversarial principle by giving the priority to procedural activity of parties and highlighting their role to claim certain facts and to give or suggest evidence to prove them upholding at the same time the principle of equality of arms. The reason of giving the priority of adversarial over the inquisitorial principle is the need to speed up the court proceedings.

\footnotetext{
${ }^{24}$ Article 120 par. 2 of the CCP.

${ }^{25}$ Article 120 par. 1 of the CCP.

${ }^{26}$ Article 118 par. 1 of the CCP.
} 


\subsection{Hearing of Both Parties Principle (audiatur et alter pars) - Contradictory Principle}

Contradictory principle is one of the general principles applicable in the Slovak civil proceeding $\mathrm{s}^{27}$ and it is closely related to the principle of equality of arms of both parties to the dispute. According to the Slovak Constitution everyone has to the right to deliver his/her opinion on all pieces of evidence ${ }^{28}$ and the Code of Civil Procedure further specifies this principle.

The contradictory principle means that nothing which could have the impact on the decision of the court, cannot be excluded from the examining in the contradictory way by both parties.

The principle aims at ensuring the situation according to which each party to the case has to have the possibility not only to propose and bring forward the evidence, which it considers necessary for the success of the claim, but also to get acquainted with each evidence and statement proposed and brought forward by the other party and to comment it. The parties are actively involved in the proceedings, since they determine what facts have to be evidenced by the court and the activity of the judge/court has only supplementary character and is limited to instructing, explaining and questioning competences of the court. However, the contradictory principle is not unlimited, especially in case when in the civil proceedings it conflicts with the need to determine in a fair and true way the facts of the case. The court has to decide the case not only on the basis of evidence submitted by the parties, but also on the basis of evidence it deems necessary to take on its own motion.

The court continues with the proceedings also in cases where the parties are passive ${ }^{29}$.

The contradictory principle as such is not specifically defined in the Slovak legal system, nonetheless according to the Slovak Constitution ${ }^{30}$ everyone has to the right to deliver his/her opinion on all pieces of evidence and the elements of this principle are further specified in the Code of Civil Procedure ${ }^{31}$ : "The parties have the equal position in the civil proceedings... The Court is obliged to ensure that they have equal possibilities to claim their rights."

The claimant is obliged together with the action bring forward also the evidence so that the defendant is served with the proposal and evidence supporting the claim. On the other hand, the defendant has also the right to comment the evidence of the claimant and to suggest evidence to be taken in order to defend him/herself.

\footnotetext{
${ }^{27}$ Case of the Constitutional Court no. I. ÚS 49/01 of 19.12.2001.

${ }^{28}$ Article 48 of the Constitution.

${ }^{29}$ Article 101 of the CCP.

${ }^{30}$ Article 48 of the Constitution.

${ }^{31}$ Article 18 of the CCP.
} 
The parties have not only the right to submit the evidence, but they are obliged to identify evidence in order to prove their claims/counterclaims. However, the court can in exceptional cases take other evidence too, if they are necessary to decide the case.

The parties have the right to comment all the suggestions for evidence and the evidence taken. $^{32}$

The court shall instruct the parties that all evidence and facts of the case have to be submitted until the decision on finalisation of evidence is taken.

The parties have the right to be present in taking of evidence and hearing of the parties, including where evidence is taken by another court or out of courtroom. The court shall inform parties about the results of taking of evidence in the hearing. The court can decide that the evidence is taken repeatedly or amended. ${ }^{33}$

The contradictory principle applies in accordance with which the parties have the right, but not the obligation to be present and to comment all the evidence taken. The court can also take default judgment where all following circumstances are met: (i) the defendant did not appear before the court in spite of s/he was summoned in time including being instructed about the consequences of his/her failure to appear about the court; (ii) the defendant did not commented the claim and evidence in written within 15 days from the delivery thereof, although s/he was instructed about consequences of his/her failure to comment; (iii) the defendant did not duly and in time excused his/her absence.

There are following preclusions to the possibility to render default judgement in cases where: (i) the judgement would constitute the establishment, change or dissolution of legal relationship between the participants, (ii) the relationship of international business is involved, (iii) the participants cannot settle their dispute (by friendly settlement approved by the court), (iv) the right for payment related to consumer contract is involved and the debtor is consumer, if the contract includes the unfair terms. ${ }^{34}$

Violation of these rights constitute the reason for cancellation of the judgement by the appellate court ${ }^{35}$.

The judgement can also be cancelled on the basis of the same reason (the party was denied the possibility to act before the appellate court) claimed by the extraordinary appeal filed within 1 month from the date when the appellate judgement became final.

The right of equal treatment is anchored in the Constitution (article 12: "Everyone is free and equal in dignity and in rights."). This principle is enshrined in the substantive

\footnotetext{
${ }^{32}$ Article 123 of the CCP.

${ }^{33}$ Article 122 of the CCP.

${ }^{34}$ Article 153 b of the CCP.

${ }^{35}$ Article 221 of the CCP stipulates that if the party was denied the possibility to act before the court, the appellate court shall cancel the judgement.
} 


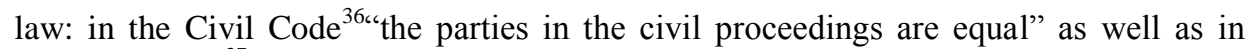
procedural law ${ }^{37}$ : "parties to the civil proceedings are equal and the court shall ensure the equal possibilities for enforcement of their rights". This right involves also the right to act before the court in one's mother tongue as well as the right for free legal aid aimed at removal of the material discrepancies between parties.

In essence the main sanction for the passivity of the party is the possibility for the court to issue the default judgement. If the plaintiff is absent, the court would decide only on the basis of his/her original proposal if it considers the facts of the case in accordance with what was included in the proposal. The court can also stop the proceedings if the incomplete proposal of the plaintiff is not amended further to the request of the court. Due to the inactivity of plaintiff s/he can loose his/her case before the court. ${ }^{38}$

The failure to provide evidence requested by the court would result to the situation where the party would loose his/her case.

According to the new Civil Contentious Code the parties are required to be procedurally active and thus have the procedural responsibility with sanctions in case of their passivity - in case of failure to make certain act, the party is precluded to do so after the expiry of the deadline (so called procedural preclusion). Parties are obliged to ascertain certain acts important for the decision to be taken and to prove them by the evidence according to the orders and instructions of the court ${ }^{39}$. To ensure the equality of arms, both parties have the right to get acquainted with statements, proposals and evidence of other party and to comment them ${ }^{40}$. For example, if the party does not identify its legal representative even in the deadline stipulated by the court, its procedural acts shall be disregarded. The court shall instruct the party about such consequences. Just to complement the whole picture, the new Civil Contentious Code enlarges the obligation to be represented by the attorney according to the criterion ratio causae, i.e. in certain matters the representation by the attorney is indispensable, which are following: cases related to bankruptcy and restructuralization, competition and unfair competition disputes, disputes related to commercial secrecy and intellectual property rights ${ }^{41}$. The Slovak legal system also recognizes the right for free legal aid for persons not having sufficient means to afford the attorney ${ }^{42}$.

\footnotetext{
${ }^{36}$ Article 2 of the Civil Code.

${ }^{37}$ Article 18 of the CCP.

${ }^{38}$ Article 43 of the CCP.

${ }^{39}$ Articles 7-8 of the Civil Contentious Code.

${ }^{40}$ Article 9 of the Civil Contentious Code.

${ }^{41}$ Article 87 of the new Civil Contentious Code.

${ }^{42}$ Law on Free Legal Aid no. 327/2005 Coll.
} 


\subsection{Principle of Orality - Right to Oral Stage of Procedure, Principle of Written Form}

The principle of orality as such ranks among the general principles of civil procedure ${ }^{43}$. This principle is specifically formulated in the Law on Judges and Assessors ${ }^{44}$, which in its article 8 paragraph 1 states that "the proceedings is oral and public as a rule, unless the law does not stipulate otherwise".

The Civil Procedure Code stipulates that "the court shall order the oral hearing with the presence of parties and other persons, if their presence is needed, unless the law stipulates otherwise" ${ }^{\text {" }}$. The oral hearing is not necessary if it does not contradict with public interest and if the case can be decided on the basis of written evidence and if parties expressly gave up their right for oral hearing. The oral hearing is not ordered in petty claims/small claims proceedings ${ }^{46}$, i.e. as a rule the court decides in written proceedings unless it deems necessary to order oral hearing.

In principle the oral form is dominant, even the written evidence is taken by the court in a hearing - the judge reads the document or summarizes its content ${ }^{47}$.

The principle of orality is dominant in the Slovak legal system. The oral hearing is conducted as a rule and it is not necessary only if the written form does not contradict with public interest ${ }^{48}$ and if the case can be decided on the basis of written evidence and if parties expressly gave up their right for oral hearing ${ }^{49}$. The oral hearing is not ordered in petty claims/small claims proceedings.

The new Civil Contentious Code also reflects the traditional principle of orality. It may be, however, overriden - the law stipulates the cases where it is not possible to order court hearing and the court can rely on the written form only. In this context the procedural criterion of value of the claim (valoris causae) is being introduced instead of previously used term small claims. The court does not have to order hearing if the subject matter concerns the legal assessment only, the ascertaining of the parties are not disputable and the value of the claim does not exceed 2.000,- eur. The oral hearing does not have to take place when the parties agree that hearing is not to be conducted. This regulation reflects the fact that evidence has to be taken only when contradicting ascertaining of the parties. The oral hearing does not have to be conducted in other cases, such as default judgment, summary procedures (payment order), etc ${ }^{50}$. The absence of oral hearing does not contradict the article 6 paragraph 1 of the European

${ }^{43}$ MAZÁK, J.: Fundamental principles of civil procedural law. Iura Edition, Bratislava 2002, p. 34.

${ }^{44}$ Law no. 335/1991 Coll. as amended.

${ }^{45}$ Article 115 of the CCP.

${ }^{46}$ Article $115 \mathrm{a}$ of the CCP.

${ }^{47}$ Article 129 of the CCP.

${ }^{48}$ Award of the Slovak Constitutional Court no. PL. ÚS 7/96 of 27.2.1997.

${ }^{49}$ ZOULÍK, F.: Court and judiciary. C.H.BECK/SEVT, Prague 1995, p. 127.

${ }^{50}$ Article 173 of the Civil Contentious Code. 
Convention for the Protection of Human Rights and Fundamental Freedoms as enshrined in the case law by the European Court on Human Rights. ${ }^{51}$

\subsection{Principle of Directness}

The principle of directness is one of the fundamental principles of the proceedings ${ }^{52}$. It is interconnected with the principle of orality ${ }^{53}$. It means that the court is in direct contact with the parties. It is the strict requirement of the proceedings in order to ensure that the court can directly and in person get acquainted with all evidence necessary to decide the case, which at the same time excludes the situation where the court would take into account evidence not taken in the proceedings ${ }^{54}$. The evidence does not have to be taken again if the judge is replaced in the civil proceedings.

The principle of directness is not defined as such in the civil codes, however, the Civil Procedure Code stipulates that "the court takes all the evidence at the hearing, unless the requirements for written procedure are met" ${ }^{\prime 55}$. The party has the right to be present at the proceedings.

The principle applies both to taking of evidence by the court as well as to the right of the party to be present at the hearing. The exemption represents the possibility to decide without oral hearing, so that the court would decide on the basis of written evidence only. The written proceedings is only conducted and the court decides without oral hearing if it does not contradict with public interest and if the case can be decided on the basis of written evidence and if parties expressly gave up their right for oral hearing. The oral hearing is not ordered in petty claims/small claims proceedings ${ }^{56}$.

Under certain specific circumstances, ${ }^{57}$ the appellate court can take additional evidence suggested by the parties, if the court of first instance did not take this evidence although the parties suggested it. It is exceptional, the evidence can only be taken when it was not taken before the first instance court and the evidence concerns the competence of the court, exclusion of judge, or it proves the failure of instructing the parties about the time limit for submitting the evidence, or when the party was not able to submit the evidence to the first instance court.

The appellate court is allowed to evaluate evidence, it can come to the conclusion that the first instance court has wrongly established the facts of the case on the basis of the

\footnotetext{
${ }^{51}$ See for example Martinie v. France; Fredin v. Sweden; Allan Jacobsson v. Sweden.

${ }^{52}$ SVÁK, J.: Selected principles of performance of judiciary. Concordia Trading, Bratislava 1996, p. 7.

${ }^{53}$ BAJCURA, A. \& coll.: Civil Procedural Law. Publishing unit of the Faculty of Law of the Comenius University, Bratislava 1995, p. 32.

${ }^{54}$ MACUR, J.: Interest of parties in explaining of the facts of the case in civil proceedings. In: Bulletin of advocacy, 2/1999, p. 10-21.

${ }^{55}$ Article 122 of the CCP.

${ }^{56}$ Article $115 \mathrm{a}$ of the CCP.

${ }^{57}$ Stipulated in article 205a of the CCP.
} 
evidence taken by it (in this case the appellate court can also repeat taking the evidence $)^{58}$.

The principle of directness is explicitly defined in article 13 of the new Civil Contentious $\operatorname{Code}^{59}$. The law stipulates in what cases the representation is obligatory and in which cases the party has to be represented by the attorney. As stated above, they are cases related to bankruptcy and restructuralization, competition and unfair competition disputes, disputes related to commercial secrecy and intellectual property rights, as well as cases involving cross border element ${ }^{60}$. The exemptions from the principle of directness always have to be interpreted in a restrictive manner.

\subsection{Principle of Public Hearing}

This principle is one of the fundamental principles of the civil proceedings. It enables citizens to be informed about the course of the proceedings and deciding by the court and thus is the important tool of control of judiciary by the citizens. ${ }^{61}$ It means that everyone is entitled to have his/her case tried at the public hearing. This principle is embodied in the duty of the court to order and conduct public hearing, including summoning of parties and other persons.

The principle of oral hearing also means that judgement has to be announced in public, irrespectively of the fact, whether the public has been excluded for the whole proceedings or for the part of it only. The failure to comply with the principle of oral hearing would result in the possibility to cancel the decision in case.

It applies to one stage of the proceedings - hearing as it is embodied in the ordering of hearing, summoning of parties and other persons. The application of the principle of public hearing is ensured by the obligation of the court to publish the list of tried cases on the notice board of the court. The principle is enshrined in the Constitution: "Everyone has the right to have his case tried in public. The public can be excluded only in cases stipulated by law." "62 According to article 116 of the CCP "the proceedings is public with the exception of hearings held by notaries when performing their function as court commissionnaires" (i.e. notaries trying the heritage proceedings in their capacity performing the function of the court).

As for the exemptions to this principle, the public can be excluded ${ }^{63}$ for the whole hearing or part of it, only if the public hearing would endanger the protection of secret

\footnotetext{
${ }^{58}$ Article 213 of the CCP.

${ }^{59}$ Article 13 par. 1: Parties act before the court in person, unless the law specifies otherwise. The parties can be represented, however, the court can hear the party also in that case, if it is necessary and possible.

${ }^{60}$ Law on Private International Law no. 97/1963 Coll.

${ }^{61}$ SVÁK, J.: Selected principles of performance of judiciary. Concordia Trading, Bratislava 1996, p. 25.

${ }^{62}$ In article 48 of the Constitution.

${ }^{63}$ Award of the Slovak Constitutional Court no. II. ÚS 58/97 of 18.2.1998.
} 
data, trade secret, important interest of parties or morality. There is no specific age limit introduced, however, if the morality is the reason for excluding the public, normally persons under 18 years of age are not allowed to the hearing. Individual persons can be banned from their participation at the hearing, if their presence could impact the dignity and smooth course of hearing. ${ }^{64}$

The principle of public hearing is also reflected in article 14 of the new Civil Contentious Code and it in fact takes over the existing regulation ${ }^{65}$, nonetheless it supplements it with the rules for video recording and video or audio transmissions from the court hearing, which can only be made with the consent of the court. ${ }^{66}$

\subsection{Principle of Pre-Trial Discovery}

The pre-trial discovery does not exist in the Slovak civil law at present.

Nonetheless, the pre-trial discovery is being introduced in the new Civil Contentious Code for the first time in the Slovak legal system. This institute, which is completely new to the civil law is introduced due to the fact, that one of the most frequent reasons for delays in court proceedings is the repetitive conduct of court hearing, ordering of supplementary and complicated expert's evidence, etc.. The new institute should thus strengthen the principle of concentration of taking evidence. The court will during this phase determine which of the claimed facts will be considered as significant and further to that it will require the parties to define clearly which evidence are to be proposed. The court will instruct the parties, that other statements and proposed evidence will not be taken into account. Besides the speeding up of court proceedings the institute of pretrial discovery should also prevent the so called surprising court decisions.

According to article 164 of the new Civil Contentious Code the conduct of pre-trial discovery is not obligatory ${ }^{67}$, however, the pre-trial discovery is expected this to be rule rather than exemption.

The aim of the pre-trial discovery is to ascertain, whether the procedural requirements are met and respectively, the measures to remedy the shortcomings can be taken by the court in cooperation with the parties. During the pre-trial discovery the court should try to seek the amicable solution of the dispute by mediation ${ }^{68}$. If the mediation failed, the court shall impose the obligations upon the parties, that are necessary to pursue the aim of the proceedings, especially as regards the preparation of the court hearing. The court shall also determine which facts claimed by the parties are still disputable, which facts are not disputable, as well as the court decides during this stage which evidence is to be taken. As a rule the court will not take evidence of the facts that are claimed in

\footnotetext{
${ }^{64}$ Article 116 of the CCP.

${ }^{65}$ Article 172 of the Civil Contentious Code.

${ }^{66}$ Par. 5 of the article 172 of the Civil Contentious Code.

${ }^{67}$ Article 164 par. 1: The court shall conduct pre-trial discovery before the first hearing, unless it decides otherwise.

${ }^{68}$ Article 166 par. 2 of the Civil Contentious Code.
} 
accordance by both parties, unless the court is of the view that there is reasonable ground to believe that their claims do not correspond the truth. The court shall also present its preliminary legal qualification of the dispute as well as the preliminary date when the court hearing takes place ${ }^{69}$. This all serves the parties to be well prepared for the main hearing. The court can also decide the case during the pre-trial stage, if it is possible and serves its purpose ${ }^{70}$.

The parties are summoned before the court for the pre-trial discovery in the same way and sticking to the same procedural requirements as in case of the court hearing. The consequence of not appearing before the court when the plaintiff or defendant were properly and timely summoned and without any serious reason did not appear is that the court can decide by the default judgement. Nonetheless, the plaintiff and defendant that are summoned have to be instructed to this effect when being summoned to the pre-trial discovery $^{71}$.

\subsection{Other General Principles}

The principle of directness (prima facie evidence taking), principle of arbitrary order (applicable where there are no special periods prescribed and where the court according to its conviction orders which act has to be taken and which evidence should be taken and also the court establishes where the evidence is sufficient to decide the case), principle of equal treatment with parties, the principle of ex officio conduct of the proceedings once the proceedings are initiated by the parties, the principle of concentration of the proceedings and principle of procedural economy are examples of other principles governing the civil proceedings in Slovakia.

However, these principles as such are not defined in the CCP in the form of introductory principles or definitions. The new Civil Contentious Code has remedied this situation when legal principles were only abstracted from the legal science and thus implemented by the judges, by introducing the introductory part called "Basic Principles". This part includes the definitions of the basic principles, which thus form the framework of interpreting rules, in accordance of which the legal norms have to be interpreted and applied. The order, in which the principles are listed and defined, does not reflect their importance. All principles are equal.

The Civil Contentious Code is based on the following principles that are enshrined in the introductory part of the Code:

- a general principle of prioritisation of courts as the authority of legal protection $^{72}$ meaning that unless the law confers this power to another authority (administrative authorities, arbitration courts), all disputes concerning the application of subjective rights in the field of substantive law are proceeded and adjudicated by the court;

\footnotetext{
${ }^{69}$ Article 167 par. 1 of the Civil Contentious Code.

${ }^{70}$ Article 167 par. 2 of the Civil Contentious Code.

${ }^{71}$ Article 168 of the Civil Contentious Code.

${ }^{72}$ Introductory article 1 of the Civil Contentious Code.
} 
- principle of legal certainty or principle of legitimate expectations meaning that the disputes are being adjudicated in accordance with the settled case law of the Slovak Constitutional Court, European Court on Human Rights, Court of Justice of the EU, etc. If the court departs from the settled case law, it has to give specific reasons for that;

- principles of interpretation of the Civil Contentious Code in accordance with the Constitution of the Slovak Republic, with public order, with fundamental values upon which the Slovak legal system is based, with international treaties binding on Slovakia having preference over the domestic legislation, with the case law of the European Court on Human Rights, Court of Justice of the European Union, including values protected by those courts ${ }^{73}$. The interpretation in accordance with the objective and aim of the provision is given priority before the interpretation in accordance with the grammar and syntax rules ${ }^{74}$; principle of interpretation by analogy (analogia legis and analogia iuris) ${ }^{75}$;

- principle of denegation iustitiae ${ }^{76}$ enabling the judge to decide the dispute even in cases where the explicit provision of the law to this end does not exist;

- principle of non-abusing the subjective rights ${ }^{77}$ according to which the court can refuse to take concrete procedural acts representing the obvious misuse of the law, moreover it can impose sanctions for such misuse;

- $\quad$ principle of equality of parties ${ }^{78}$ (also referred to as the principle of equality of arms) with the focus on the new strengthened concept of adversarial proceedings. It reflects the case law of the European Court on Human Rights which perceives the principle of equality as the possibility to take part in the procedural acts of another party and to comment it. The specific position of parties reflecting their weaker social position and unfavourable health conditions should be taken into account as well;

- free disposition principle which governs almost entirely the contentious procedure is enshrined especially in the initiative of the parties to submit their claims before the court, being thus the prerequisite for the whole proceedings to commence $^{79}$;

- adversarial and inquisitorial principle ${ }^{80}$ (principle of material truth) which both are related to the principle of equality of arms and free disposition principle. As stated above the new Civil Contentious Code gives priority to the procedural activity of parties to the dispute, who are obliged to ascertain the facts and to indicate evidence to prove them while both parties have the right to be acquainted and to comment the ascertaining of the counterparty;

\footnotetext{
${ }^{73}$ Introductory article 3 par. 1 of the Civil Contentious Code.

${ }^{74}$ Introductory article 3 par. 2 of the Civil Contentious Code.

${ }^{75}$ Introductory article 4 par. 1 of the Civil Contentious Code.

${ }^{76}$ Introductory article 4 par. 2 of the Civil Contentious Code.

${ }^{77}$ Introductory article 5 of the Civil Contentious Code.

${ }^{78}$ Introductory article 6 of the Civil Contentious Code.

${ }^{79}$ Introductory article 7 of the Civil Contentious Code.

${ }^{80}$ Introductory article 8 and 9 of the Civil Contentious Code.
} 
- principle of arbitrary order is the one of the basic principles of the contentious proceedings ${ }^{81}$ according to which it is up to the court to determine the course and timeline of the proceedings with regard to the principle of economy in order to pursue to objectives pursued by the law. The Civil Contentious Code as a rule does not impose the procedural deadlines on the judge, it enables the judge to concentrate certain procedural acts by the parties and to impose sanctions in case of failure to take acts by the parties within the binding time limits specified by the judge (procedural preclusion) - in the form of not having the possibility to make the act anymore after the expiry of such imposed binding time limit;

- principle of regarding the procedural acts of the parties in accordance with their content and real will of the parties ${ }^{82}$, which represents the indicative rule for the court;

- principle of orality ${ }^{83}$ imposed on the communication between parties and the court is in some cases overrided by the modern means of communication, especially in the cases of small claims;

- principle of directness $^{84}$ applicable on the communication of the party with the court, including the right to be present during taking of evidence by the court if taken outside the hearing;

- principle of public control over judicial power ${ }^{85}$ implies the right to be present at the hearing even without the necessity to prove the legal interest in the subject matter of the dispute. The public can be excluded from the hearing only in cases stipulated by the law (morality, secrecies, protection of privacy);

- principle of free assessment of evidence ${ }^{86}$ represents the fundamental principle of evaluation of evidence by the court. None of the means of evidence has the priority over others. This imposes the requirements for the proper justification of the decisions of the court;

- principle of legality ${ }^{87}$ meaning the obligation of the judge to be bound by the law while respecting the hierarchy of the legal norms, including the supremacy of the EU law, priority of the international treaty binding on Slovakia and promulgated according to the law. The principle of legality in the Civil Contentious Code implies that the court shall not take into account facts and evidence obtained illegally, however, in some cases this can be justified by applying the overriding right;

- principle of procedural economy ${ }^{88}$ as one of the fundamental interpretation rule of this Code represents the equivalent and supplements the right for legal and judicial protection, which has to be legal and effective and thus speedy (justice delayed is justice denied);

\footnotetext{
${ }^{81}$ Introductory article 10 of the Civil Contentious Code.

${ }^{82}$ Introductory article 11 of the Civil Contentious Code.

${ }^{83}$ Introductory article 12 of the Civil Contentious Code.

${ }^{84}$ Introductory article 13 of the Civil Contentious Code.

${ }^{85}$ Introductory article 14 of the Civil Contentious Code.

${ }^{86}$ Introductory article 15 of the Civil Contentious Code.

${ }^{87}$ Introductory article 16 of the Civil Contentious Code.

${ }^{88}$ Introductory article 17 of the Civil Contentious Code.
} 
- principle of free circulation of court decisions ${ }^{89}$ in the European Union according to which the decisions of the foreign courts enjoy the same degree of judicial protection as the domestic decisions.

\section{General Principles of Evidence Taking}

\subsection{Free Assessment of Evidence}

This principle ranks among the fundamental principles in the Slovak legal system. It means that the court freely assesses the evidence, as the law does not stipulate any degree of credibility of individual types of evidence nor it establishes the value of them. The court evaluates the individual pieces of evidence in their entirety, but also in their mutual correlation. The judge is not bound by any legal norms when assessing the evidence $^{90}$. "The court assesses the evidence according to its own conclusions, based on experience and logic." 91

The court is not bound by the parties' dispositions, it can take any evidence it deems necessary for ascertaining the facts of the case. The court is obliged to assess only evidence which, according to its conviction, lead to the fair decision in matter. The evidence taken by the court has to be taken also with regard to the principle of equality of parties and in accordance with requirements which do not favour any of parties ${ }^{92}$. The court decides which from among the evidence suggested by the parties will be taken $^{93}$.

The obligation of the court to provide due reasoning of its decision, where it has to explain upon which evidence it has based the decision and why it did not take other evidence as suggested by the parties can be considered as the form of controlling mechanism in this context.

The judge assesses the evidence irrespectively of whether it was suggested by the parties or on his/her own motion. The judge is guided by the necessity to ascertain the facts of the case and has to examine every piece of evidence s/he deems necessary in order to find the material truth. The court cannot only base its decision on the statements of parties or ascertained facts, but it has to base its decision on the results of taking of evidence and facts ascertained by such evidence taking.

The judge assesses the evidence to the best of his/her belief, which does not, of course, mean that the court assesses the evidence arbitrarily and contra legem. On the contrary, the judge when assessing the evidence has to take into account all the circumstances of the case and to evaluate it both individually and in their mutual correlations. The evidence taking procedure has to be objective, transparent and reviewable.

\footnotetext{
${ }^{89}$ Introductory article 18 of the Civil Contentious Code.

${ }^{90}$ Article 132 of the CCP.

${ }^{91}$ ZOULÍK, F.: Court and judiciary. C.H.BECK/SEVT, Prague 1995, p. 130.

${ }^{92}$ Award of the Slovak Constitutional Court no. PL ÚS 25/01 of 7.11.2002.

${ }^{93}$ Article 120 of the CCP.
} 
The judge assesses the evidence to the best of his/her belief while taking into account all the circumstances of the case and evaluating the evidence both individually and in their mutual correlations. The principle is defined as follows: "The evidence is assessed by the court according to its considerations, each piece of evidence individually and also in their mutual correlation while carefully taking into account of all facts ascertained during the proceedings, including what has been stated by the parties."94

The judge assesses the evidence to the best of his/her belief while taking into account all the circumstances of the case and evaluating the evidence both individually and in their mutual correlations. The principle is defined as follows: "The evidence is assessed by the court according to its considerations, each piece of evidence individually and also in their mutual correlation while carefully taking into account of all facts ascertained during the proceedings, including what has been stated by the parties." 95

The principle of free assessment of evidence as the fundamental principle of evaluation of evidence by the court is reflected also in the new Civil Contentious Code ${ }^{96}$, which explicitly stipulates that none of the means of evidence has the stronger probative role and thus does not have the priority over other means evidence. The fact that no hierarchy of the means of evidence exists imposes the more strict requirements for the proper justification of the decisions of the court, which has to give specific reasons why certain evidence was considered as more convincing for the court.

\subsection{Relevance of Material Truth}

This principle ranks also among fundamental principles of civil proceedings in the Slovak legal system, although it is only implicitly formulated. It supplements the principle of free assessment of evidence. The principle of material truth requires the pragmatic knowledge of probability of existence of certain facts, which are decisive for deciding the case and which are so probable, that under the free, but due assessment of the judge they are reaching the border of certainty. On the other hand, this principle, which was promoted as one of the most fundamental principles in the socialistic legal theory, has been subject to some revisions, in particular when strengthening the adversarial principle in the civil proceedings.

There are limitations to this principle. The evidence has to be taken in such a way that the duty of secrecy as defined under the special legal regulations, is kept. Hearing of such witness can thus be made only if the competent authority or person, to the benefit of which such duty is imposed, have withdrawn the duty of secrecy. ${ }^{97}$ Also the confessional privilege can be the reason of refusal to testify. ${ }^{98}$ The testimony by witness can also be denied, if such testimony can pose the risk of criminal prosecution to the

\footnotetext{
${ }^{94}$ Article 132 of the CCP.

${ }^{95}$ Article 132 of the CCP.

${ }^{96}$ Introductory article 15 of the Civil Contentious Code.

${ }^{97}$ Article 124 of the CCP.

${ }^{98}$ Article 126 of the CCP.
} 
person involved or to his/her close persons; the court decides about the reasons to refuse to testify.

There are no limitations for the court to select the evidence irrespectively of whether it was suggested by the parties or by the court. The judge is guided by the necessity to ascertain the facts of the case and has to examine every piece of evidence s/he deems necessary in order to decide the case.

There is a general obligation of the parties to cooperate with the court established in the Code of Civil Procedure ${ }^{99}$. There is also a duty to testify - every natural person is obliged to appear before the court and to testify as a witness ${ }^{100}$. Article 131 of the CCP establishes the duty of the parties to appear before the court and to testify. There is also a duty to appear before the expert witness and to provide explanations and to submit required items or give explanations ${ }^{101}$, or to undergo medical check, blood test, etc. ${ }^{102}$ Finally, there is also duty to provide documentary evidence to the court ${ }^{103}$ established in the Code of Civil Procedure.

There is no limitation of the right to propose new facts and evidence (ius novorum). The parties can propose the evidence throughout the whole proceedings - the court ${ }^{104}$ declares before the end of proceedings that the stage of taking of evidence is closed and after that only it is not possible to submit the new evidence.

There are no special standards of material truth established in the law. The court has to be convicted about the facts of the cases on the basis of examination of evidence taken. "The evidence is assessed by the court according to its considerations, each piece of evidence individually and also in their mutual correlation while carefully taking into account of all facts ascertained during the proceedings, including what has been stated by the parties." 105

The principle of directness (as described bellow) also ranks among the general principles of evidence taking in the Slovak legal system and is also reflected in the new Civil Contentious Code in its Introductory articles 8 and 9 in connection with the inquisitorial principle. Both are related to the principle of equality of arms and free disposition principle. As stated above the new Civil Contentious Code strengthens the role of the procedural activity of parties, who are obliged to ascertain the facts and to indicate evidence to prove them and it is up to the court to establish the facts of the case.

\footnotetext{
${ }^{99}$ Article 6 of the CCP.

${ }^{100}$ Article 126 of the CCP.

${ }^{101}$ MACUR, J.: Explanation duty of party not having the burden of proof in civil proceedings. In: Legal Horizon 5/2000, p. 200 and subs.

${ }^{102}$ Article 127 of the CCP.

${ }^{103}$ Article 128 and article 130 of the CCP.

${ }^{104}$ According to article 118 of the CCP.

${ }^{105}$ Article 132 of the CCP.
} 
The relevance of material truth is even more visible in the context of non-contentious proceedings. The new Civil Non-contentious Code reflects this principle being applied in a larger manner together with the inquisitorial principle and principle of officiality which are typical for these types of proceedings requiring a higher degree of protection and thus larger interference of the judge.

\section{Evidence in General}

All kinds of evidence and methods of proof are equal, no proof is considered as stronger than others. The only exception is "public document", which is the document issued by the courts or other state authorities within the framework of their competence, as well as documents declared as public documents directly by law. The court considers its content as proven.

There are no formal rules of evidence, only basic rules provided in the Code of Civil Procedure. ${ }^{106}$ There are certain procedural rules governing taking of individual kinds of evidence (e.g. instructing a witness before his/her examination, methods of summoning, way of taking the evidence of expert witness, etc.). If the method of taking of evidence is not stipulated in the Code of Civil Procedure, the court shall determine it. There is no formal minimum standard of proof, it is within the discretion of the court to consider the evidence individually and in their mutual correlations.

As stated above, this attitude of no prioritisation of the respective means of evidence is also confirmed in the new Civil Contentious Code especially in its introductory article 15. The focus is thus given on the principle of free evaluation of evidence and the court has to give fair and proper justification in its decisions and its argumentation in the reasoning of decision has to be clear, convincing and logically undisputable. The introductory principle 15 of the new Civil Contentious Code explicitly states that no evidence has its legally prescribed evidentiary strength or probative role.

\subsection{Means of Proof}

The definition of evidence is provided in article 125 of the CCP "everything can serve as evidence in order to ascertain the facts of the case, in particular hearing of witnesses, report of expert witness, reports and statements of authorities, natural and legal persons, documents, inspection of place/thing and hearing of parties". ${ }^{107}$ The list of evidence is not enumerative, it only gives the means of evidence by way of example. The means of proof are: hearing of witnesses; reports of expert witnesses; reports and statements of authorities, natural and legal persons, written documents; inspection of place or thing; hearing of parties; anything that could serve the court as a mean to ascertain the facts of the case.

There is no provision excluding certain means of evidence from the possible modes of proof. Anything that could serve the court as a mean to establish the facts of the case

\footnotetext{
${ }^{106}$ Articles 120 to 136 of the CCP.

${ }^{107}$ Article 125 of the CCP.
} 
can be the evidence. The examination of parties is also considered as one of the means of evidence. As regards parties, there are no special constraints for their capability to testify. As for underage, there is no special limit in the Slovak law, a child can be heard with regard to its age and mental maturity. In the practice of Slovak courts even child under age of 2 years can be heard. Neither disability is regulated as the constraint for testifying.

The party testimony can be requested by the parties or it can be ordered by the court itself, if it considers this evidence necessary to ascertain the facts of the case. There are no limits to the facts they can testify about. Only the secrecy, including professional secrecy or secrecy as stipulated by the special laws can be considered as limitations. Also the confessional privilege represents the limit of the obligation to testify.

The testimony by witness can be denied, if such testimony can pose the risk of criminal prosecution to the person involved or to his/her close persons; the court decides about the reasons to refuse to testify. The party can refuse to testify, if such testimony can pose the risk of criminal prosecution to the person involved or to his/her close persons. ${ }^{108}$ In this case it is possible both to refuse entirely the testimony or to refuse answering certain questions. The court decides about the reasons to refuse to testify and evaluates it.

If the refusal to testify is considered unlawful, it would have the result that the court cannot establish the particular fact of the case which would have the effect on the final decision as the decision of the court has to be based on the facts as established by the evidence taken. If the party refuses to testify without any reason, the court can impose fine and can order the party to appear before the court and provide testimony. ${ }^{109}$

There is no oath prescribed in the Slovak law. Nonetheless, the parties have to be instructed by the judge that they have to tell the truth and not to conceal anything. The penalty for perjury is the deprivation of liberty of 1 year to 5 years, although for qualified offence the sanction is higher, under very special circumstances it can be up to 10 years $^{110}$.

There are no special rules for evaluating evidence gathered trough parties testimony. Their evidence is evaluated as other pieces of evidence. The adversarial principle and the possibility to comment all the evidence submitted by the other party serves to the court to ascertain duly the facts of the case on the basis of the evidence by the parties.

There is no special type of evidence prescribed for certain facts. However, in the practice it is established that only public documents can prove certain facts (for example certificate of marriage is accepted as the evidence submitted in the proposal for divorce).

\footnotetext{
${ }^{108}$ Article 126 of the CCP.

${ }^{109}$ Article 53 of the CCP.

${ }^{110}$ Article 345 of the Criminal Code.
} 
The existence of rights arising out of a cheque or bill of exchange cannot be proven by any other means than presentation of such document, i.e. the cheque or bill of exchange have to be submitted to the court. ${ }^{111}$

There is no degree of value of evidence; the only exemption is the public document (document issued by the court or competent authority). There are no special methods of proof prescribed as obligatory by law. However, there are certain types of procedures, in principle proceedings related to personal status, proceedings involving minors and divorce proceedings), where concrete factual status has to be proven by certain document. In mentioned proceedings the existence of concluded marriage is proven.

Parties are obliged to deliver evidence both together with their claim/defence statement or upon the request of the court. They are obliged upon the request of the court and without delay to produce in written any facts relevant for the decision of the court.

The court can order any person, i.e. including parties to submit document or other evidence. $^{112}$

If a person who is to be examined before the court or expert witness does not appear without justification, s/he can be brought before the court by the police (upon the previous instruction that the failure to appear before the court can mean that the person would be brought before court - article 52 of the $\mathrm{CCP}$ ). The plaintiff can also be forcibly brought before the court under same conditions.

The person can also be imposed fine for not producing or delivering evidence - up to 820 eur, and in case of gros deterioration of the proceedings before the court the fine can be imposed in the amount up to 1.640 eur. ${ }^{113}$ The third person has a duty to deliver evidence.

As for the judicial and administrative decisions and their value as evidence, these decisions are considered as public documents and are considered as established fact, they do not have to be proven. If it happens that they are proven to be false/not true the court in civil proceedings is bound by the decision of the criminal court.

Documents issued by the courts or other competent state authorities, as well as documents considered as public by virtue of special laws, confirm that it is the regulation or declaration of the issuing authority, and, unless it is proved contrary, also the verity of what is certified or confirmed by the document ${ }^{114}$.

The new Civil Contentious Code distinguishes between the term evidence and the term means of evidence. As regards evidence, in addition to the existing definition ("all that contribute to ascertaining of certain matter") it introduces the concept of legally

\footnotetext{
${ }^{111}$ Article 175 of the CCP.

112 Article 129 of the CCP.

${ }^{113}$ Article 273a of the CCP.

${ }^{114}$ Article 134 of the CCP.
} 
obtained evidence: "All that can contribute to ascertain certain matter and was obtained legally from the means of evidence can be serve as the evidence." 115

At the same time the new Civil Contentious Code takes over the demonstrative enumeration of the means evidence from the previous Civil Code with slight adjustments as to the terminology (for example it replaces the term "hearing a participant" by "hearing a party" and "expert evidence" instead of "expert opinion". It explicitly states that means of evidence are in particular hearing of a party, hearing of a witness, document, expert explanation, expert evidence and inspection of a thing/place. If the way of taking evidence is not stipulated, it shall be determined by the court ${ }^{116}$.

The new legal regulation changes the value of sanctions for not producing evidence - in the amount up to 500,- eur and in case of repetitive failure the amount has been increased up to 2.000 ,- eur. The court has not the possibility to forgive payment of the sanction anymore, as this would mean that the educative effect of the sanction is not fulfilled.

\section{General Rule on the Burden of Proof}

Parties are equal before the court, i.e. the claimant is the one who addresses the court and thus has to prove his/her allegations. According to the Constitutional Court ${ }^{117}$ the right to fair trail includes the principle of "equality of arms" in the civil proceedings, which reflects the duty to bear the burden of proof, as well as the principle of "equality of parties" in the civil proceedings reflected in creating the equal procedural conditions and equal procedural status of subjects, whose rights and obligations are to be decided upon by the court". It means in principle it is the claimant who bears the burden of proof, with certain exceptions.

The court has to ascertain the level of probability of existence of certain facts decisive for evaluating the issue, that are so probable, that according to the free but due consideration are close to the level of certainty. In the justification of the judgement the court has to spell out what facts are considered as proven (and what are not). The justification of the judgement has to be persuasive.

The well known facts or facts known to the court from its activity do not have to be proven, as well as the legal regulations published in the Collection of Laws of the Slovak Republic and in the Official Journal of the European Union do not have to be proven ${ }^{118}$. Also the fact, for which the presumption is established by the law allowing the evidence to prove the contrary, does not have to be proven by the court, unless the contrary is ascertained in the proceedings. The court can also establish the facts on the basis of the consensual allegations of both parties.

\footnotetext{
${ }^{115}$ Article 183 of the Civil Contentious Code.

${ }^{116}$ Article 183 par. 2 of the Civil Contentious Code.

${ }^{117}$ Award of the Constitutional Court no. II ÚS 121/02.

118 Article 121 of the CCP.
} 
The defendant has the general duty to comment all claims and facts submitted by the claimant - if not, under special conditions (the defendant does not appear in spite of being duly summoned nor s/he asks for adjournment due to serious reasons) the judgement in absentia may be issued.

The court can $^{119}$ impose the defendant in written by its resolution to take a position in written to the case and if s/he does not agree with the claim, to submit relevant facts and evidence. The court prescribes the time limit to the defendant for such reaction.

The doctrine iura novit curia is known to the Slovak legal system. In accordance with it the legal regulations published in the Collection of Laws of the Slovak Republic and in the Official Journal of the European Union do not have to be proven ${ }^{120}$. It means that only facts are being evidenced, as the legal regulations must be known for the court. As for the foreign law, the parties need just to identify it, and the court has to find out the content of it (through the Ministry of Justice) ${ }^{121}$.

If the facts claimed by a party and the proposed evidence are incomplete, the judge shall invite the party to correct or amend his/her proposal to start proceedings within the stipulated time limit (not less than 10 days) ${ }^{122}$. This duty of the court is views as the balance to the adversarial principle guiding the civil proceedings.

The court has means to induce parties to elaborate on claims and express an opinion on any factual or legal matter. The court can impose duty to this effect on parties by its resolution, including the time limit. In case of failure to comply with this resolution the court can impose repeatedly the monetary fine up to the amount of 1.640 eur (one sum not exceeding 820 eur $)^{123}$.

The summoned party which does not appear upon notification can be brought before the court upon previous notification (that in case of failure to appear s/he can be brought by the police before the court). This information about the possibility to induce parties to that effect can be provided in writing, as well as during hearings parties can be instructed to that effect by the judge.

The court can invite the parties to submit additional evidence, and also parties can do it on their own motion, until the moment when the judgement is promulgated, i.e. until the very last moment of the proceedings. In proceedings where no oral hearing is ordered, the court before issuing the judgement formally closes the evidence by the resolution ${ }^{124}$. The main consequence for cases when the party does not comply with the court's request for production of evidence is that the party is unable to prove his/her case and can loose it. And also as stated above party may be compelled by the court to appear (by

\footnotetext{
${ }^{119}$ Article 114 of the CCP.

${ }^{120}$ Article 121 of the CCP.

${ }^{121}$ Law no. 97/1963 Coll. on Private International and Procedural Law as amended.

${ }^{122}$ Article 43 of the CCP.

${ }^{123}$ Article 53 of the CCP.

${ }^{124}$ Article 120 of the CCP.
} 
bringing the party by the police before the court) as well as by imposing the monetary fines for failure to cooperate with the court in producing/bringing evidence.

The court can collect evidence on its own initiative in civil cases, in the proceedings which can be initiated by the court on its own motion - so called non contentious proceedings, which include proceedings to allow to conclude marriage, to determine and deny paternity, about feasibility of adoption, cases related to commercial register, cases related to some issues concerning companies and cooperatives, the court is obliged to collect and take all the evidence. In the contentious proceedings the court can also collect evidence on its own initiative in order to ascertain the material truth. The reason is that in case of non-contentious proceedings there is the public interest in ascertaining the facts of the case so that it can be decided, unlike in classical adversarial (contentious) cases where it is in the parties' interest to propose the evidence in the support of his/her allegations.

If during the presentation of evidence new facts that were previously not raised by parties become known, the court may allow additional submission of the evidence. The court can allow additional evidence until the moment when the judgement is to be promulgated in the case. The party is only obliged to suggest, i.e. to indicate the evidence and the court can summon the third person to submit it or to appear before the court.

The new Civil Contentious Code confirms the principle of equality of arms. As regards burden of proof, it specifically states that in so called anti-discrimination cases the burden of proof is shifted from the plaintiff to the defendant in order to strengthen the protection of weaker party. In this type of cases the inquisitorial principle prevails, as it is in case of non- contentious proceedings As it was stated above, in order to strengthen the principle of arbitrary order and concentration of proceedings, the principle of procedural activity of the parties to the dispute is being strengthened by introducing the sanctions for the passive party in the form of loosing the possibility to make certain act after the deadline imposed by the court. This is introduced with the aim to speed up proceedings by shifting the procedural and evidential burden from the court towards the parties to the dispute.

The procedural economy is mainly strengthened by the institute of pre-trial discovery, whereby the time limits for submitting or indicating certain evidence are imposed from the side of the judge. If the judge is persuaded about the facts of the case, s/he can decide the case on the basis of evidence presented during the pre-trial discovery. This is in line with the overarching principle of the new Civil Contentious Code - the principle of arbitrary order.

The situation, when the court can also establish the facts on the basis of the consensual allegations of both parties is being supplemented by introducing the requirement that there is reasonable ground to believe that such consensual allegation does not correspond the truth. 
A new element introduced into the new regulation is the explicit reference to the possibility of the court to take evidence ex officio in connection with public register, if the allegations of the parties are not in accordance with the reality ${ }^{125}$. Also without being requested the court can take evidence in order to establish, whether the decision to be taken will be enforceable, as well as to find the foreign law ${ }^{126}$.

The new Civil Contentious Code keeps the concept of so called editorial and information obligation of the parties and third persons in relation to the court. Unlike the current wording of the CCP imposing the obligation to provide written information to the court to anyone for the compensation, the compensation is not introduced in the new Civil Contentious Code as in reality it was difficult to estimate the value of compensation to be paid.

The new Civil Contentious Code introduces the sanctions for passive party to the dispute on the basis of the principle of procedural diligence of the parties - both to the plaintiff and defendant who can both loose the case in case of failure to appear before the court although being properly summoned.

As regards non-contentious proceedings, the inquisitorial principle and the principle of material truth, as well as the activity of the judge remains the guiding principle. The reason for this is the need to ensure the legal certainty and the protection of basic values, such as the protection of family, status of a person, protection of best interest of a minor, and the protection of values with the aim to preserve legal certainty.

\section{$5 \quad$ Written Evidence}

\subsection{The Concept of a Document}

The notion of document is defined in our legal system as "any final not empty consequence of signs." 127 There is also specific definition for example in the proceedings concerning the commercial register. Video and audio recording are not considered as a document within the Slovak legal system. As for the electronic documents, only the proposals to start proceedings sent electronically with secured electronic signature are considered as documents. They are considered as equivalent to any other form of proposal (made in written, orally documented in the official minutes). However, an electronic version of a document is not considered to be equivalent to a document in the current Code of Civil Procedure, which uses the term "deed" which includes only written form of document.

The secured electronic signature is recognised in our legal system. The electronically secured signature counts is defined as "the information attached or otherwise connected with the electronic document, which should fulfil following requirements ${ }^{128}$ :

\footnotetext{
${ }^{125}$ Article 181 par. 2 of the Civil Contentious Code.

${ }^{126}$ Article 181 par. 3 of the Civil Contentious Code.

${ }^{127}$ Article 2 of the Law on electronic signature no. 215/2002 Coll.

${ }^{128}$ Article 3 of the Law on electronic signature no. 215/2002 Coll.
} 
a) it cannot be effectively made without the knowledge of private key and electronic document,

b) it is possible to verify on the basis of this information and public key belonging to the private key used in order to produce it, that the electronic document, to which it is attached or otherwise logically connected, is identical with the electronic document used to its production,

c) it contains information identifying the author of the signature.

The author of the signature shall produce electronic signature of the electronic document in such a way that s/he on the basis of his/her private key and electronic document produces the new data fulfilling the requirements under letters a) to c).

The electronic signature has the same probative value as the original signature.

\subsection{Documents for Which a Presumption of Correctness Exists}

They are so called public documents. The "public document" is the document issued by the courts or other state authorities within the framework of their competence, as well as documents declared as public documents directly by law ${ }^{129}$. The court considers its content as proven. The fact, that the content of those document is incorrect has to be contested and its incorrectness proven in the proceedings. There is no formal difference if the contents are contested or when the fact that it is the public document is contested.

There is no value of evidence established, i.e. every piece of evidence is evaluated by the court independently and in mutual correlations irrespectively of the fact, whether it is private or public. Private evidence has to be proven, i.e. the adversarial nature of proceedings serves to ensure that the objective facts in the case are established by the court. The Slovak legal system does not recognize the categorisation of private evidence.

It is up to the court to find out the facts of the case after hearing both parties in a contradictory way ${ }^{130}$. The contradictory character of the proceedings implies the contesting the evidence proposed by one party by another and vice versa ${ }^{131}$. The law draw distinction between the evidential (probative) value of public and private documents in two aspects: in case of "public documents" (the documents issued by courts and other public authorities) and also in case of report of expert witness. If the party submits the report of expert witness, this has lower evidential value as when the report is ordered by the court.

The written evidence is taken by reading it by the court at the hearing ${ }^{132}$. The court can order any person to submit the written evidence before the court. The parties are obliged

\footnotetext{
${ }^{129}$ Article 134 of the CCP.

${ }^{130}$ ECtHR case Mantovanelli v. France of 18.3.1997.

131 ZOULÍK, F.: Equality of parties and professionality of civil proceedings. In: Bulletin of advocacy $9 / 99$, p. 125.

${ }^{132}$ Article 129 of the CCP.
} 
to accompany their proposal to start proceedings with the written evidence/documents ${ }^{133}$. During the proceedings, any person (including party) is obliged to submit the document to the court, or to ask for the document from the competent authority and to submit it to the court. The documents have to be produced in their original version or in authenticated copy.

The new Civil Contentious Code keeps the concept of the written document as one of the means of evidence with the differentiation between the public and private documents having the consequence as to the necessity to prove $i^{134}$.

\section{Witnesses}

\subsection{Status of a Witness}

Every natural person is obliged to appear before the court and to testify ${ }^{135}$. The court summons the witnesses. The parties only identify the witness they want to testify. The witness can only refuse to testify, if his/her testimony could cause the criminal prosecution to him/herself or to his/her close persons. The close person is defined as the relative in direct order, sibling and spouse. Other persons in family or other relationship are considered as close persons if the injury caused to one person is perceived as the injury by the other person too.

The person has to either appear in court or to excuse him/herself in written.

The failure to appear after being properly summoned by the court can be sanctioned by the fine.

\subsection{Right to Refuse to Testify}

It is the discretion of the court to decide about the reasons of refusal to testify, i.e. if they are justifiable or not. There isn't formal possibility to contest it as the court does not decide by formal decision (resolution). Nonetheless there is a possibility to comment every piece of evidence in general. In general, there are no persons to be deemed as unfit to be a witness. Even minor can testify, there is no limitation by age. Under some circumstances priests can refuse to testify (secrecy of confession). Such persons, if they have been summed, can claim their right not to testify before the court who will decide, if the reason is justifiable.

The privilege against self-incrimination exist in the law. A person can only refuse to testify, if his/her testimony could cause the criminal prosecution to him/herself or to his/her close persons. It is the discretion of the court to decide about the reasons of refusal to testify, i.e. if they are justifiable or not. This discretion is limited to assessing

\footnotetext{
${ }^{133}$ Article 79 of the CCP.

${ }^{134}$ Articles 200-201 of the Civil Contentious Code.

135 Article 126 of the CCP.
} 
the justifiable character of the reasons as they are stipulated in the law, so in practice the court does not examine the content of the grounds.

The right to refuse to give evidence is not linked to certain persons/profession, but to the content of secrecy. The evidence has to be taken in such a way that the secrecy about the facts protected by the special laws or other secrecy established or recognised by the state, is preserved ${ }^{136}$.

The right to refuse to testify does not apply absolutely, i.e. those persons can be released from the secrecy by the authority which implied the secrecy. The Code of Civil Procedure does not enumerate the kinds of secrets as they are regulated by separate laws. Among them are business secrecy, state secrecy, military secrecy, health secrecy, secrecy of advocate, journalist protecting his source.

For example, if a general manager of legal person has to be examined by the court not as the witness but as the party to the proceedings, the consequence of refusal to testify may be that the case will be lost. If s/he is called as a witness in case where his/her company is not the party and recalls the business secrecy, the court would accept it. If such a company is a holder of concession or public service, the evidence has to be taken in such a way that the secrecy about the facts protected by the special laws or other secrecy established or recognised by the state, is preserved. The fact, that the company is the public law entity does not affect this issue.

If a state official refuses to testify about certain fact, claiming that it represents a state secret., the court will address the state authority, which obliged its official by secrecy obligation, to release him/her from this duty.

The journalist can be released from the duty to protect his/her source by this source or by the court, i.e. s/he is covered by the privilege of the sources. The court in deciding about the withdrawal of secrecy has to balance interests on both sides. The court asks the respective entity for withdrawal, for example when withdrawing the secrecy of notaries, the court asks Notarial Chamber, in case of legal counsels, the court asks Bar Association for withdrawal. The court itself can only withdraw professional secrecy in relation to expert witnesses. There is no appeal against the decision of the court not to allow to testify in breach of secrecy.

The secrecy of confession is accepted directly by the law as the ground for refusal to testify $^{137}$.

The patient or the court can withdraw the obligation of secrecy in case of medical doctor. Only the patient himself/herself can agree to provide details about her/his health status. It is up to the court to balance both interests and to confirm/withdraw the right to refuse to testify. There is no appeal against the decision of the court to allow/not to allow to testify in breach of secrecy.

\footnotetext{
${ }^{136}$ Article 124 of the CCP.

${ }^{137}$ Article 126 of the CCP.
} 
An attorney at law (advocate) may also refuse to testify about certain facts regarding his client. Only the client or the court can withdraw the obligation of secrecy. It is up to the court to balance both interests and to confirm/withdraw the right to refuse to testify. Again, there is no appeal against the decision of the court to allow/not to allow to testify in breach of secrecy. As for other legal professions that can rely upon same privilege, they are: notaries and huissiers de justice. Huissiers de justice are court bailiffs, i.e.self employed legal profession responsible for enforcement of court decisions. Both notaries and huissiers de justice have the duty to keep secrecy in relation to personal and business information provided by their clients.

A witness cannot be forced to take an oath, since the Slovak legal order does not recognise examining the witness under oath. This is not going to be change after July 1 , 2016.

The new Civil Contentious Code in fact does not change the system of right to refuse to testify, including the secrecies.

\subsection{Obtaining Evidence from Witnesses}

The judge has to establish the identity of the witness at the beginning of examining, as well as all circumstances that can influence his/her credibility. The judge asks about the relation of the witness to the parties to the case and to the dispute/subjects in question in order to find out whether the witness is credible. In case the identity of the witness has to remain secret, his/her affiliation to organisation/entity has to be established instead.

The judge has also the duty to instruct the witness about the importance of his/her testimony, about his/her rights and as well as about the criminal consequences of the false testimony. Subsequently the court examines the witness, i.e. invites him/her to describe all circumstances of the case and facts. Then the judge asks the witness questions in order to amend and clarify his/her testimony.

The delivering party has the right to ask the witness questions after the judge asked the questions. The opposing party has the right to ask questions after the judge asked the questions. As to the way of production of evidence, in principle it depends from the delivering party which way it suggests. Once the party suggest the oral testimony of a witness, the witness is summoned before the court and s/he may be instructed, that failure to appear before the court can have the consequences of being brought before it. The law does not prescribe any limits to the facts they can testify about, however, the court questions the witness, so the court is responsible for the way the witness is examined.

Penalty for the perjury is the sanction of deprivation of liberty of 1 year to 5 years, although for qualified offence the sanction is higher, under very special circumstances it can be up to 10 years $^{138}$.

${ }^{138}$ Article 345 of the Criminal Code. 
There are no special rules for evaluating special types of evidence as the disposition of free assessment of testimony applies.

Cross examination is not known to our civil proceedings as a principle, but in practice both parties can ask witnesses questions during their questioning.

As to the concept of questioning witness based on the historical tradition of the Slovak civil procedural law, the new Civil Contentious Code introduces the new features, which are related to the new concept of strictly adversarial procedure.

The concept of sworn affidavit is introduced for the first time into the Slovak civil law as the written form of evidence instead of questioning a witness ${ }^{139}$. The purpose and effectiveness have to be considered by the judge when ordering this type of evidence. Nonetheless, the witness has to be accordingly instructed about the eventual criminal consequences of perjury, In fact, this represents the difference from the so called written statement, which has the character of private document without presuming obligation to be instructed and thus without the potential threat of criminal consequences of perjury.

Both sworn affidavit and written statement are to be considered in accordance with the principle of free assessment of evidence.

The new Civil Contentious Code also changes the system of ensuring the presence of the witness at the proceedings in accordance with the strengthened adversarial principle - the presence of the witness is to be ensured by the party and the court's interference is only subsidiary ${ }^{140}$. The party ensuring the presence of the witness has to inform the court and the other party of the dispute in order to ensure the proper defence and preparedness for the questioning of this witness in advance.

In order to address practical difficulties the new regulation specifies that in case it is not possible to ensure the presence of the witness, neither by the party nor by the court, the court shall decide that such witness shall not be examined ${ }^{141}$.

The principle of confrontation of witnesses is explicitly introduced in order to reflect the adversarial principle. The possibility for witnesses to pose questions to each other is introduced $^{142}$. The structure of examining a witness in the structure ad generalia and $a d$ specialia is being kept by the new Civil Contentious $\operatorname{Code}^{143}$. As for the conduct of examining of the witness, it is explicitly expected that the parties will pose questions, and the court only on a subsidiary basis.

\footnotetext{
${ }^{139}$ Article 192 of the Civil Contentious Code.

${ }^{140}$ Article 193 of the Civil Contentious Code.

${ }^{141}$ Article 194 of the Civil Contentious Code.

${ }^{142}$ Article 195 par. 2 of the Civil Contentious Code.

${ }^{143}$ Article 198 of the Civil Contentious Code.
} 


\section{$7 \quad$ Taking of Evidence}

There is no mandatory sequence in which evidence has to be taken. Anyone, who possesses the evidence has to bring it to the court, i.e. the parties do not have to take the evidence from the witnesses, just to identify it and the court will ask directly the person identified to bring the evidence in court.

The court shall determine the deadline when allowing taking of evidence The deadline has the procedural character. The order of the court has to contain the deadline, or the exact date and the consequences of failure to comply with it. Following from the principle that it is up to the court to establish the facts of the case, the fact, that the evidence is not produced in time does not have the effects of "direct sanction". If the evidence is presented before the final phase of the proceedings, the court will still take it into account. If the evidence is not produced at all, this would have the adverse effect on the decision, as the court will not be able to rely on it. The court finally evaluates all the evidence before issuing the judgement, the court decides about the evidence until all pieces of evidence are taken.

The court can secure the evidence upon the proposal of the party (and ex officio in noncontentious proceedings) before or during the main hearing by protective measure, for example, it can ask for certain evidence to be brought before it at the very beginning of proceedings, or it can ban the person to dispose of certain evidence item. To secure the evidence the court has to take all measures to preserve it so that it can be taken in due time. This is done in the stage before the proceedings starts.

The evidence can also be taken outside the proceedings, if it is not possible to bring the subject to the court room. The parties have the right to be present.

\subsection{Rejection of an Application to Obtain Evidence}

In the stage before the proceedings the court collects applications to take evidence. The court is free to decide which of them will be taken. The application to obtain evidence can be lodged during the proceedings too, again the court is free to decide about it. There are no special reasons stipulated by the law in order to reject the application to obtain evidence, it is in the discretion of the court, which is only bound by the goal to ascertain the true facts of the case.

The refusal must be based on the same reasons as the ground to refuse to testify, i.e. the confession secrecy, state secrecy, military secrecy, etc. The court cannot reject an application to take evidence, if the request was not submitted in time; the parties can suggest evidence anytime during the proceedings. The application can be submitted until the decision of the court about the closure of evidence is taken, i.e. until the very end of the proceedings.

The parties are obliged (and it is in their interest) to identify the evidence they are suggesting as well as possible, i.e. name, address, the claims, etc. In case they do not 
know all whereabouts of the person identified as a witness, the court can use its capacity to assist in identification. The court would not refuse to take the evidence if the parties do not state the facts, the court would find all missing elements by itself.

In general, the court can use all facts that has learned in its activity. Especially the court is bound by other court's decision in criminal case having link with the current proceedings. In the activity of the court means that facts established in proceedings but also outside proceedings - for example facts established by other court that are relevant in the matter. It is not necessary to take the evidence of the facts, which the court has learned in its activity ${ }^{144}$. Such knowledge has the same value as the knowledge about the laws published in the Collection of Laws or EU legislation published in the Official Journal.

\subsection{The Hearing}

The evidence is as a matter of principle taken at the hearing and if it is taken outside the hearing (in cases where no oral hearing is ordered), both parties have the right to be present in taking the evidence. The principle of directness ranks among the fundamental principles of the civil proceedings. Only the court can take evidence, the competent court proceeding in case can ask another court to take the evidence, if it is more appropriate due to distance, etc. The court can ask another court to take the evidence, if it is more appropriate due to distance, etc.

The court can ask another court to take the evidence, if it is more appropriate from the point of view of procedural economy. It is only in appeal proceedings, where the new evidence can be taken (or the evidence suggested by the party and not taken by the court in the first instance).

There is also the possibility to re-open the proceedings from serious reasons, among them is that there are new evidence that cannot be taken without the fault of the party (i.e. due to the facts that the party could not influence) or that can bring more favourable decision for one party and could not be taken. There are no special rules regulating the order of taking different types of evidence.

The parties have the right to be present in taking the evidence ${ }^{145}$. Nonetheless, it is their right, not their obligation.

The Slovak legal system formally does not distinguish it, although the principle of directness ranks among the fundamental principles of our civil procedure. The judge evaluates all pieces of evidence, both direct and indirect. The indirect evidence, unless it is excluded by the direct evidence taken, can assist in establishing the facts of the case too. The video conference represents the direct type of evidence. The court can use the video conference to conduct the hearing ${ }^{146}$. It would not be possible to do it abroad

\footnotetext{
${ }^{144}$ Article 121 of the CCP.

${ }^{145}$ Article 122 of the CCP.

${ }^{146}$ Article 116 of the CCP.
} 
without the consent of the local court. The evidence taking court proceeds as a rule without the direct participation unless it is specifically requested by the court asking for the evidence. The court can hold hearing using the videoconference or using other communication means with the consent of the parties. However, the audio or video recording is only possible with the consent of the court.

As for the conduct of examining of the witness, the new Civil Contentious Code foresees that the court will pose questions to the witness only on a subsidiary basis. Mainly the parties are to pose questions.

\subsection{Witnesses}

The court shall summon the witness as identified by the party. The court delivers the summon with certificate and instructs the witness about the consequences of nonappearance. The court delivers through post with the certificate of delivery. There is no obligation for the parties to adduce the written statement before the testimony.

The witness does not swear an oath, the witness is only instructed about the importance of his/her testimony, about his/her rights and as well as about the criminal consequences of the false testimony/perjury. The witnesses are questioned individually. There is no special preparation for witnesses. There is no difference whether the party is or is not instructed by the party/representative, i.e. no special consequences are attributed.

As it was stated above, the new regulation introduces the possibility for the court to refuse examining the witness who cannot be found. This procedural decision has to be justified by the court. Also the adversarial character is being strengthened by the new Civil Contentious Code by the fact that the questions are supposed to be posed by the parties to the dispute as a principle, as well as by the fact that witnesses can pose questions to each other.

\subsection{Expert Witnesses}

The judge is examining witness and posing questions to the expert ${ }^{147}$. The parties can also pose questions to the expert witness. The same procedure is followed when experts or when ordinary witnesses are questioned; in both cases the same procedure for questioning is used, i.e. the court is examining both expert and witness.

The judge can summon any person to appear before the expert. The judge can also ask any person or institution to cooperate with the expert, to provide explanations, to bear certain acts (e.g. medical check, blood test) of the expert, to bring certain documents or items to the expert, etc. The court can examine the expert, or can be satisfied only with his/her written report. The court appoints the expert from the list of certified experts ${ }^{148}$.

\footnotetext{
${ }^{147}$ Article 127 of the CCP.

${ }^{148}$ Law no. 382/2004 Coll. on Expert Witnesses, Interpreters and Translators.
} 
The party has the duty to cooperate with expert, to provide explanations, to bear certain acts (e.g. medical check, blood test) of the expert, to bring certain documents or items to the expert, etc. In principle if they do not agree, the consequence is that the fact is viewed as proven (i.e. person refusing blood test is considered as father in paternity dispute).

The opposing party has the same duties to cooperate with expert, to provide explanations, to bear certain acts (e.g. medical check, blood test) of the expert, to bring certain documents or items to the expert, etc. The opposing party has the right to comment the expert witness report. It is up to the court: in principle the expert produces written opinion, and upon the summoning of the court, s/he has to appear before the court and to present his/her report.

The experts are selected from a list of registered experts, which is kept by the Ministry of Justice. The same rules apply governing the taking of evidence from an expert appointed by the court and an expert appointed by the parties. However, their probative value is different: the report from the expert appointed by the court has the higher value as the report produced by the expert appointed by the party. In general the parties can present private expert report as evidence. In case of expert appointed by the party it is that party, which can claim the reimbursement from the unsuccessful party; and in case of expert witness appointed by the court the fees are part of the court fees. The decision about the court fees and reimbursement is taken at the end of the proceedings together with the judgement.

They have the right to propose another expert and the court will decide about their request. The court is free to appoint several experts in the case, if it has doubts.

The written evidence is considered as one form of evidence and has not preference over the testimony, i.e. the judge is not bound by the content of written evidence. As for the written expert opinions, they are presented before the court by reading the whole or the summary of it. In case of irregularities, the court can also summon the expert.

The new Civil Contentious Code for the first time regulates the expert opinion submitted by the party without the expert being appointed by the court. Such solution corresponds to the adversarial character of the proceedings based where the procedural diligence of the parties implies that it is up to the parties to bear the result of the case.

\section{Costs and Language}

\subsection{Costs}

The term "legal expenses" includes the lawyers' fees. The lawyers' fees include the award for the performance of lawyer in the form of tariff award (and not contractual award), and the loss of profit and reimbursement of travel costs, if the lawyer has to 
travel to the court. The remuneration for the lawyer is based on the tariff fees, and not on the basis of contractual fees ${ }^{149}$.

Every party pays for costs of taking the evidence, which occurred on his/her account. Joint costs are paid according to the proportion of participation at the matter and at the proceedings. In heritage proceedings the heir shall bear the costs of notarial fees and expenses (as the notary acts upon the authorisation of the court). For example the costs of bringing the person who does not appear voluntarily upon being summoned by the court are borne by this person. The party which suggests securing the evidence pays the payment of guarantee.

The advance payment may be imposed by the court in relation to party, which has suggested the evidence, it is up to the consideration of the court and depends on the amount of taking the evidence expected (and not on the type of evidence). The costs of taking the evidence which are not covered by the advance payment are covered by the state. As for the rules regarding the taking of evidence ex officio, the costs are borne by the state. The costs of parties already spent in proceedings that could be commenced ex officio (non-contentious proceedings) are not refundable. As for heritage proceedings, the costs of notary (who acts upon the authorization of the court) are borne by the heir(s) unless the estate is in loss.

As for the traveling costs, the compensation for appearance of a witness before a court includes the traveling costs and the lump sum for lost salary. The traveling costs is calculated in terms of actual costs (travel ticket if public transport is used, or in terms of kilometers, if the car is used) and the lost salary per day spent at court and traveling to/from the court.

The requesting court pays:

- the real expenses that occurred to the expert,

- the compensation for the time of expert,

- remuneration of the expert.

The court pays for all costs of interpretation, as the right to communicate in the mother tongue, or the language the party understand, is guaranteed and it is up to the court to ensure the enjoyment of this right ${ }^{150}$. There are no special circumstances stipulated in cases where the procedural expenses must be paid by the requesting court due to special procedure or technology in cross border cases in accordance with provisions of Regulation on Taking of Evidence ${ }^{151}$. In practice the advance payment could be asked

${ }^{149}$ Decree of the Ministry of Justice no. 655/2004 Coll. on Remuneration and Compensation of Lawyers for Providing of Legal Services.

${ }^{150}$ Judgement of the Czechoslovak Supreme of 28.4.1984, $1 \mathrm{Cz} 15 / 84$ c. 21/1986; ECtHR case Luedicke, Belkacem a Koc v.Federal Republic of Germany of 28.11.1978.

${ }^{151}$ Council Regulation (EC) no. 1206/2001 of 28 May 2001 on cooperation between the courts of the Member States in the taking of evidence in civil or commercial matters, OJ L 174, 27.06.2001. 
for in case of evidence which foresees higher level of expenses, such as DNA tests. In those cases the expert would ask for advance payment.

In most of domestic cases it happens more often that advance payment is asked (for example if the advance payment is asked by the expert), in cross border cases this happens rarely and in such cases it was reimbursed later.

The new Civil Contentious Code does not in fact change the existing regulation of the costs, however, it principle it simplifies it.

\subsection{Language and Translation}

The courts have to use professional accredited interpreters. If both judge and the parties understand the witness, the interpretation is not necessary. The langue is defined as the "language to which the witness understands". The accredited translators are responsible for translating the documents. Before being accredited, they are sworn (i.e. not before every case). In principle all documents have to be in the "language of the court".

The official court interpreter is always appointed when a witness is questioned. If the witness understands the language of the proceedings and renounces the interpretation, it is not provided. The court shall bear the costs of interpretation.

The videoconference is rarely used in practice in Slovakia as not every court is equipped by the VCF device. The interpreter is provided in order that both parties and the court understand the questions.

\section{Unlawful Evidence}

The Slovak legal system does not recognize the distinction in civil and commercial litigation between "illegally obtained evidence" and "illegal evidence". There is any normative solution establishing the illegality of the mean of obtaining evidence either. The evidence is taken by the court and there is a presumption that the court does not act contra legem. For example, the court would have to question a witness in contradiction with secrecy (state secrecy, military secrecy). If the presented document was falsified or if the police acted illegally when obtaining some information, this evidence cannot be used and even the whole case can be reopened, including after proceedings was closed. Accordingly, there is no legal concept or definition of "legal evidence" or "Illegal evidence". There is no normative solution establishing the illegality of evidence. As stated above, the evidence is taken by the court and there is a presumption that the court does not act contra legem. However, by means of example, the court would not take the evidence which is recorded illegally.

The principle of legality in the Civil Contentious Code implies that the court shall not take into account facts and evidence obtained illegally, however, in some cases this can be justified by applying the overriding right, for example if the court takes into account the electronic communication taken without the consent of the respective person, it has 
to justify it by stating that the right for privacy is weaker in relation to the constitutional right, which was allegedly infringed by the infringement of privacy. In practice such constitutional right may be for example the discrimination.

\section{Taking of Evidence Regulation}

Council Regulation (EC) No 1206/2001 of 28 May 2001 on cooperation between the courts of the Member States in the taking of evidence in civil or commercial matters is based upon the principle, that the evidence is taken by the requested court in accordance with its procedures applicable for taking of evidence under national law. Taking the evidence using the special procedures according to the article 10 of the Regulation can be refused only by reason of major practical difficulties, not merely by reason of its non-existence in the national law.

As for the notifications made in accordance with article 22, the competent courts to take the evidence in Slovakia are first instance district courts. The central authority under article 3 of the Regulation is the Ministry of Justice of the Slovak Republic, Division for Private International Law and International Judicial Co-operation. As for the language skills notified under article 3, they are Slovak, Czech, English, French, German.

As for applicable provisions for taking the evidence when the Slovak court is requested court, they are included in the Code of Civil Procedure - "Občiansky súdny poriadok" (Act no. 99/1963 Coll. as amended). Unfortunately, the official English translation of the CCP is not available.

As for the treaties notified under article 21 paragraph 3 of the Regulation No 1206/2001, Slovakia has unilaterally notified bilateral treaties with 3 states as more favourable: with the Czech Republic, Hungary and Poland (none of those countries have notified those treaties). Therefore those arrangements do not apply (see manual to the 1206/2001 Regulation).

Treaty between the Slovak Republic and the Czech Republic on Mutual Legal Assistance Provided by Judicial Authorities and the Regulation of Certain Legal Relations in Civil and Criminal Matters with Final Protocol (Prague 29 October 1992).

Treaty between the Czechoslovak Socialist Republic and the Hungarian People's Republic on Mutual Legal Assistance and the Regulation of Legal Relations in Civil, Family and Criminal Matters (Bratislava 28 March 1989).

Treaty between the Czechoslovak Socialist Republic and the Polish People's Republic on Manual 1206 /2001 Mutual Legal Assistance and the Regulation of Legal Relations in Civil, Family, Labour and Criminal Matters (Warsaw 21 December 1987). 


\section{Conclusions}

The principles in the civil procedure are enshrined in the introductory provisions of the Slovak Code of Civil Procedure. They are important not only for legislator when drafting the laws, but they also in the process of judicial interpretation of the law and its practical application before the court. The overarching aim of principles applied in the civil procedure is the principle of fairness of proceedings as deducted from the right to fair trail guaranteed in article 6 of the European Convention for the Protection of Human Rights as well as article 47 of the Charter of Fundamental Rights of the European Union.

The role of principles is also to enable for achieving more quality judicial decisions in the individual court proceedings. There are two major tendencies in the development of interpretation and application of principles in the civil procedure: the approximation with the European standards enshrined in the human rights protection framework and the fair trial principle at one side and efforts aimed at making the civil procedure more effective and expeditious, at the other side.

Traditionally in civil law countries, to which Slovakia ranks, the officiality principle has been prevailing fixing the judge into the role of active master of the case being obliged to ascertain the material truth by his/her own initiative after the application to commence proceedings by one party was filed with the court. Through the last decades and the urgent need to reduce the workload of judges and make the court proceedings more swift and efficient the principle of free disposition of parties has been introduced in a larger extent into the Slovak civil procedural law. Making the application of legal institutes more swift and improving the enforceability of rights also ranks among aims pursued by the application of principles of civil procedure. This is also achieved by introducing further elements of adversarial rather than traditional inquisitorial principle.

Another principle, not to be omitted, is the principle of predictability, legal certainty and improved access to justice. Natural and legal persons claiming their rights are in the very centre of civil justice are. The adversarial principle is therefore interconnected with the principle of equality of parties in the proceedings which is the pre-requisite of the right to fair trail. The pre condition for the enjoyment of these rights in the course of civil procedure is their knowledge - and the right to information, which should also be equal for all parties. The principles of orality and directness of proceedings as well as the principle of public hearing also help in achieving the goal of having the equal access to information.

Taking of evidence as suggested by the parties and their evaluation in accordance with the principle of principle of free assessment of evidence ranks among the core activities of the judge. The principle of material truth and directness when taking the evidence at the court are crucial for reaching the fair judgement at the end of the proceedings. In the Slovak legal doctrine all means of evidence are equal and the judge evaluates them in all their interconnections in order to verify the objective picture of the claim. Some principles, such as directness and the principle of oral hearing have the tendency to 
disappear from the second instance proceedings, which is justified by the interest in speedy, effective and reasonable decision in terms of costs.

These goals are also pursued in the newly adopted Code of Contentious Proceedings, Code of Non-Contentious Proceedings and Code of Administrative Proceedings, which will enter into force as of $1^{\text {st }}$ July 2016 and which introduces further measures aimed at making the civil proceedings more effective and less consuming in terms of money and time. 
Evidence in Civil Law - Slovakia

Jana Vnuková

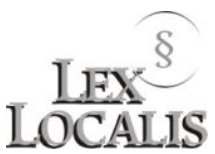

\section{Part II - Synoptical Presentation}

\section{$1 \quad$ Synoptic Tables}

\subsection{Ordinary Civil Procedure Timeline According to the Slovak Legal System}

\begin{tabular}{|c|c|c|c|c|}
\hline $\begin{array}{l}\text { Phase } \\
\#\end{array}$ & $\begin{array}{l}\text { Name of the Phase } \\
\text { Name of the Phase } \\
\text { in National } \\
\text { Language }\end{array}$ & $\begin{array}{l}\text { Responsible } \\
\text { Subject }\end{array}$ & $\begin{array}{l}\text { Duties of the Responsible } \\
\text { Subject (related only to } \\
\text { Evidence) and } \\
\text { Consequences of their } \\
\text { Breach }\end{array}$ & $\begin{array}{l}\text { Rights (related only to } \\
\text { Evidence) of the } \\
\text { Responsible Subject }\end{array}$ \\
\hline 1. & $\begin{array}{l}\text { Preliminary } \\
\text { procedures } \\
\text { ("predbežné } \\
\text { konania"): } \\
\text { a. settlement } \\
\text { ("zmier") } \\
\text { b. preliminary } \\
\text { measures and } \\
\text { securing the } \\
\text { evidence }\end{array}$ & Court & $\begin{array}{l}\text { The court upon proposal } \\
\text { (or without proposal in } e x \\
\text { officio proceedings) has to } \\
\text { secure evidence and to } \\
\text { take preliminary measures. } \\
\text { Failure to do so can have } \\
\text { the consequence of } \\
\text { responsibility of concrete } \\
\text { judge if it is ascertained in } \\
\text { disciplinary proceedings } \\
\text { that it was subjective fault. }\end{array}$ & $\begin{array}{l}\text { The court has to establish, } \\
\text { that the friendly } \\
\text { settlement would not } \\
\text { contradict the law. } \\
\text { The court can order } \\
\text { parties to bring the } \\
\text { evidence, to pay certain } \\
\text { necessary amount of } \\
\text { money, to give certain } \\
\text { amount to the deposit of } \\
\text { the court, not to dispose } \\
\text { of certain things, to act or } \\
\text { to refrain from acting, not } \\
\text { to enter certain house or } \\
\text { dwelling, to refrain from } \\
\text { acting infringing or } \\
\text { threatening the } \\
\text { copyrights, to give child } \\
\text { to his parent, etc. }\end{array}$ \\
\hline 2. & $\begin{array}{l}\text { Application ("návrh" } \\
\text { or "žaloba") }\end{array}$ & Claimant & $\begin{array}{l}\text { Claimant has the duty to } \\
\text { indicate evidence } \\
\text { supporting his claim. If } \\
\text { claimant fails to identify } \\
\text { the evidence, s/he may } \\
\text { loose the case as the court } \\
\text { will decide upon the facts } \\
\text { of the case established on } \\
\text { the basis of evidence } \\
\text { identified. }\end{array}$ & $\begin{array}{l}\text { Claimant can has the right } \\
\text { to ask the other party to } \\
\text { produce evidence via } \\
\text { court's order. }\end{array}$ \\
\hline 3. & $\begin{array}{l}\text { Establishing the } \\
\text { jurisdiction } \\
\text { ("založenie } \\
\text { právomoci") }\end{array}$ & Court & $\begin{array}{l}\text { Court has to establish that } \\
\text { it has jurisdiction on the } \\
\text { basis of the domicile } \\
\text { address of natural person, }\end{array}$ & - \\
\hline
\end{tabular}




\begin{tabular}{|c|c|c|c|c|}
\hline & & & $\begin{array}{l}\text { seat of company, address } \\
\text { of immovable property, } \\
\text { etc. }\end{array}$ & \\
\hline 4. & $\begin{array}{l}\text { Examining of } \\
\text { conditions for } \\
\text { proceedings } \\
\text { ("skúmanie } \\
\text { podmienok } \\
\text { konania") } \\
\end{array}$ & Court & $\begin{array}{l}\text { Court can ask parties and } \\
\text { third parties, institution for } \\
\text { documents, statements } \\
\text { evidencing the conditions } \\
\text { for proceedings } \\
\text { (procedural capacity, etc.). }\end{array}$ & - \\
\hline 5. & $\begin{array}{l}\text { Preparatory stage for } \\
\text { hearing ("príprava } \\
\text { pojednávania") }\end{array}$ & Court & $\begin{array}{l}\text { The court delivers } \\
\text { application together with } \\
\text { annexes to defendant and } \\
\text { instructs parties. } \\
\text { The court without delay } \\
\text { delivers the statement of } \\
\text { defendant to the claimant. }\end{array}$ & $\begin{array}{l}\text { The court can impose on } \\
\text { defendant by resolution to } \\
\text { produce statement within } \\
\text { stipulated deadline. If this } \\
\text { is not complied with, the } \\
\text { court can issue default } \\
\text { judgement. }\end{array}$ \\
\hline 6. & $\begin{array}{l}\text { Ordering the hearing } \\
\text { ("nariadenie } \\
\text { pojednávania") }\end{array}$ & Court & $\begin{array}{l}\text { The court summons the } \\
\text { parties. }\end{array}$ & - \\
\hline 7. & $\begin{array}{l}\text { Hearing } \\
\text { ("pojednávanie") }\end{array}$ & $\begin{array}{l}\text { Court } \\
\text { Parties }\end{array}$ & $\begin{array}{l}\text { At the beginning of } \\
\text { hearing the court informs } \\
\text { parties about evidence it } \\
\text { intends to take. } \\
\text { The court takes the } \\
\text { evidence and evaluates it. } \\
\text { Parties are obliged to } \\
\text { appear before the court } \\
\text { and produce evidence. }\end{array}$ & $\begin{array}{l}\text { The court can take } \\
\text { evidence suggested by the } \\
\text { parties, but also any } \\
\text { evidence it deems } \\
\text { necessary in order to } \\
\text { establish the facts of the } \\
\text { case. }\end{array}$ \\
\hline 8. & $\begin{array}{l}\text { Declaration of } \\
\text { judgement } \\
\text { ("vyhlásenie } \\
\text { rozsudku") }\end{array}$ & Court & - & - \\
\hline
\end{tabular}




\subsection{Comparison Table}

1.2.1 Following table applies in case of Slovak court in a position of requesting judge in a process of taking evidence under the regime of national law, bilateral treaties, Hague convention on Taking of Evidence Abroad in Civil and Commercial Matters and Taking of Evidence Regulation.

\begin{tabular}{|c|c|c|c|c|}
\hline $\begin{array}{r}\text { Legal } \\
\text { Regulation }\end{array}$ & National Law & Bilateral Treaties & $\begin{array}{c}\text { Multilateral } \\
\text { Treaties }\end{array}$ & $\begin{array}{l}\text { Regulation } \\
1206 / 2001\end{array}$ \\
\hline $\begin{array}{c}\text { Hearing of } \\
\text { Witnesses by } \\
\text { Mutual } \\
\text { Legal } \\
\text { Assistance } \\
\text { (Legal Aid) }\end{array}$ & $\begin{array}{l}\text { The national } \\
\text { judge has to use } \\
\text { Regulation } \\
1206 / 2001 \text {, } \\
\text { Hague } \\
\text { convention on } \\
\text { Taking of } \\
\text { Evidence or } \\
\text { bilateral treaty to } \\
\text { request hearing } \\
\text { of witness. If } \\
\text { there is no treaty } \\
\text { basis, the } \\
\text { provisions of } \\
\text { Private } \\
\text { International Act } \\
\text { will apply. }\end{array}$ & $\begin{array}{l}\text { The bilateral treaties } \\
\text { include provisions on } \\
\text { hearing a witness. } \\
\text { Unlike bilateral treaties } \\
\text { with CZ, PL or HU, } \\
\text { which include direct } \\
\text { contacts - but cannot } \\
\text { be used anymore, the } \\
\text { used bilateral treaties } \\
\text { (with Russian } \\
\text { Federation, Republic } \\
\text { of Serbia) require the } \\
\text { sending of request via } \\
\text { central authorities. } \\
\text { Bilateral treaties do not } \\
\text { allow for summoning } \\
\text { of witness with the use } \\
\text { of coercive measures. }\end{array}$ & $\begin{array}{l}\text { The request under } \\
\text { the Hague Taking of } \\
\text { Evidence } \\
\text { Convention shall be } \\
\text { sent using the form } \\
\text { and central authority } \\
\text { channels. } \\
\text { The special method } \\
\text { or procedure may be } \\
\text { requested, unless } \\
\text { this is incompatible } \\
\text { with the internal law } \\
\text { of the requested state } \\
\text { or it is impossible by } \\
\text { reason of its internal } \\
\text { practice and } \\
\text { procedure or by } \\
\text { reason of practical } \\
\text { difficulties. }\end{array}$ & $\begin{array}{l}\text { The court shall } \\
\text { use the form(s) } \\
\text { provided by the } \\
\text { Regulation } \\
1206 / 2001 . \\
\text { The special } \\
\text { procedure can } \\
\text { be required, if it } \\
\text { does not } \\
\text { contradict with } \\
\text { the law of the } \\
\text { requested state. } \\
\text { The same } \\
\text { applies for } \\
\text { coercive } \\
\text { measures. }\end{array}$ \\
\hline $\begin{array}{l}\text { Hearing of } \\
\text { Witnesses by } \\
\text { Video- } \\
\text { conferencing } \\
\text { with Direct } \\
\text { Asking of } \\
\text { Questions }\end{array}$ & $\begin{array}{l}\text { The national law } \\
\text { enables hearing a } \\
\text { witness using a } \\
\text { videoconference. }\end{array}$ & $\begin{array}{l}\text { There are no } \\
\text { provisions to that } \\
\text { effect in bilateral } \\
\text { treaties. }\end{array}$ & $\begin{array}{l}\text { There is no } \\
\text { provision on } \\
\text { videoconference in } \\
\text { the Hague } \\
\text { convention on taking } \\
\text { of evidence. }\end{array}$ & $\begin{array}{l}\text { The regulation } \\
\text { enables hearing } \\
\text { a witness using } \\
\text { a } \\
\text { videoconference } \\
\text { - the requesting } \\
\text { court can ask } \\
\text { for it to be used. }\end{array}$ \\
\hline $\begin{array}{c}\text { Direct } \\
\text { Hearing of } \\
\text { Witnesses by } \\
\text { Requesting } \\
\text { Court in } \\
\text { Requested } \\
\text { Country }\end{array}$ & $\begin{array}{l}\text { There are no } \\
\text { provisions } \\
\text { specifically } \\
\text { allowing for } \\
\text { Slovak court to } \\
\text { direct hear a } \\
\text { witness in } \\
\text { another country. }\end{array}$ & $\begin{array}{l}\text { There are no } \\
\text { provisions to that } \\
\text { effect in bilateral } \\
\text { treaties. Nonetheless, } \\
\text { the treaties include } \\
\text { provision that the } \\
\text { requested authority can } \\
\text { upon the request of } \\
\text { requesting country use } \\
\text { procedural provisions } \\
\text { of requesting country, } \\
\text { unless they are in } \\
\text { contradiction with its } \\
\text { legal system. }\end{array}$ & $\begin{array}{l}\text { The Hague } \\
\text { convention does not } \\
\text { include provision on } \\
\text { direct hearing; } \\
\text { judicial authority of } \\
\text { the requesting state } \\
\text { has the right to be } \\
\text { present at the } \\
\text { hearing. }\end{array}$ & $\begin{array}{l}\text { The regulation } \\
\text { enables direct } \\
\text { hearing a } \\
\text { witness by the } \\
\text { requesting } \\
\text { court. }\end{array}$ \\
\hline
\end{tabular}




\subsubsection{Table following example of Slovak court in a position of a requested court judge in a process of taking evidence.}

\begin{tabular}{|c|c|c|c|c|}
\hline $\begin{array}{r}\text { Legal } \\
\text { Regulation }\end{array}$ & National Law & $\begin{array}{c}\text { Bilateral } \\
\text { Treaties }\end{array}$ & Multilateral Treaties & $\begin{array}{c}\text { Regulation } \\
1206 / 2001\end{array}$ \\
\hline $\begin{array}{c}\text { Hearing of } \\
\text { Witnesses by } \\
\text { Mutual } \\
\text { Legal } \\
\text { Assistance } \\
\text { (Legal Aid) }\end{array}$ & $\begin{array}{l}\text { Hearing of } \\
\text { witness in } \\
\text { accordance with } \\
\text { the Code of } \\
\text { Civil Procedure. } \\
\text { The parties have } \\
\text { the right to be } \\
\text { present during } \\
\text { hearing. }\end{array}$ & $\begin{array}{l}\text { Bilateral treaties } \\
\text { refer to the } \\
\text { national law as to } \\
\text { the concrete ways } \\
\text { of hearing a } \\
\text { witness, i.e. } \\
\text { witness will be } \\
\text { heard in } \\
\text { accordance with } \\
\text { the Code of Civil } \\
\text { Procedure. } \\
\text { Bilateral treaties } \\
\text { do not allow for } \\
\text { summoning of } \\
\text { witness with the } \\
\text { use of coercive } \\
\text { measures. }\end{array}$ & $\begin{array}{l}\text { The Hague } \\
\text { Convention on } \\
\text { Taking of Evidence } \\
\text { Abroad refers to } \\
\text { national procedural } \\
\text { law of the requested } \\
\text { state, i.e. the } \\
\text { provisions of the } \\
\text { Slovak Code of Civil } \\
\text { Procedure shall apply. } \\
\text { If a special method or } \\
\text { procedure is } \\
\text { requested by the } \\
\text { requesting state, the } \\
\text { requested state } \\
\text { follows it, unless this } \\
\text { is incompatible with } \\
\text { the internal law of the } \\
\text { State of execution or } \\
\text { is impossible of } \\
\text { performance by } \\
\text { reason of its internal } \\
\text { practice and } \\
\text { procedure or by } \\
\text { reason of practical } \\
\text { difficulties. } \\
\text { The requested } \\
\text { authority shall apply } \\
\text { the appropriate } \\
\text { measures of } \\
\text { compulsion in the } \\
\text { instances and to the } \\
\text { same extent as } \\
\text { provided by its } \\
\text { internal law. }\end{array}$ & $\begin{array}{l}\text { The regulation refers } \\
\text { to the national law in } \\
\text { case of concrete ways } \\
\text { of hearing a witness. } \\
\text { If a special procedure } \\
\text { is required, the } \\
\text { requested court shall } \\
\text { comply with such a } \\
\text { requirement, } \\
\text { unless this procedure } \\
\text { is incompatible with } \\
\text { the law of the } \\
\text { performance of the } \\
\text { taking of evidence or } \\
\text { by reason of major } \\
\text { practical difficulties. } \\
\text { The requested court } \\
\text { shall apply the } \\
\text { appropriate coercive } \\
\text { measures in the } \\
\text { instances and to the } \\
\text { extent as are provided } \\
\text { for by the law of the } \\
\text { requested Member } \\
\text { State. }\end{array}$ \\
\hline $\begin{array}{c}\text { Hearing of } \\
\text { Witnesses by } \\
\text { Video- } \\
\text { conferencing } \\
\text { with Direct } \\
\text { Asking of } \\
\text { Questions }\end{array}$ & $\begin{array}{l}\text { Slovak national, } \\
\text { which would } \\
\text { apply, } \\
\text { recognizes the } \\
\text { possibility of } \\
\text { using the } \\
\text { videoconference. } \\
\text { As for the } \\
\text { practice, }\end{array}$ & $\begin{array}{l}\text { Bilateral treaties } \\
\text { do not include } \\
\text { provision to that } \\
\text { effect, however, } \\
\text { referring to } \\
\text { national law } \\
\text { allow its use. Not } \\
\text { all Slovak courts } \\
\text { are equipped by } \\
\end{array}$ & $\begin{array}{l}\text { Hague convention on } \\
\text { taking of evidence } \\
\text { does not regulate this } \\
\text { issue. Nonetheless, it } \\
\text { refers to national law } \\
\text { when taking the } \\
\text { evidence, i.e. it could } \\
\text { be used. } \\
\text { The only practical }\end{array}$ & $\begin{array}{l}\text { The requested Slovak } \\
\text { court could, in } \\
\text { principle, comply } \\
\text { with such a } \\
\text { requirement as } \\
\text { allowed by the } \\
\text { Regulation, however } \\
\text { not Slovak courts are } \\
\text { equipped with }\end{array}$ \\
\hline
\end{tabular}




\begin{tabular}{|c|l|l|l|l|}
\hline & $\begin{array}{l}\text { unfortunately } \\
\text { not all courts are } \\
\text { equipped with } \\
\text { the video } \\
\text { conference } \\
\text { facility. }\end{array}$ & $\begin{array}{l}\text { the video } \\
\text { conference } \\
\text { device. }\end{array}$ & $\begin{array}{l}\text { difficulty is that not } \\
\text { all Slovak courts are } \\
\text { equipped by the video } \\
\text { conference device. }\end{array}$ & $\begin{array}{l}\text { videoconference } \\
\text { device. }\end{array}$ \\
$\begin{array}{l}\text { There are no } \\
\text { provisions to } \\
\text { that effect in the } \\
\text { national } \\
\text { procedural law. } \\
\text { Requesting } \\
\text { Court in } \\
\text { Requested } \\
\text { Country }\end{array}$ & $\begin{array}{l}\text { There are no } \\
\text { provision to that } \\
\text { effect in the } \\
\text { bilateral treaties, } \\
\text { however, Slovak } \\
\text { court could allow } \\
\text { it on the basis of } \\
\text { reciprocity. }\end{array}$ & $\begin{array}{l}\text { The Hague } \\
\text { convention does not } \\
\text { include provision on } \\
\text { direct hearing; } \\
\text { judicial authority of } \\
\text { the requesting state } \\
\text { has the right to be } \\
\text { present at the hearing. } \\
\text { However, on the basis } \\
\text { of reciprocity the } \\
\text { Slovak court could } \\
\text { allow for it. }\end{array}$ & $\begin{array}{l}\text { The regulation } \\
\text { a witness by the } \\
\text { requesting court, i.e. } \\
\text { the Slovak court } \\
\text { would allow it unless } \\
\text { it would not } \\
\text { contradict public } \\
\text { order. }\end{array}$ \\
\hline
\end{tabular}


Evidence in Civil Law - Slovakia

Jana Vnuková

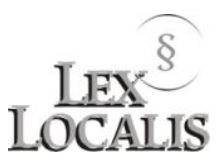

\section{References}

\section{Table of Cases}

Award of the Constitutional Court of the Slovak Republic file no. II. ÚS 47/99 of $9^{\text {th }}$ June 1999 published in the Collection of Awards under no. 25/99 (http://portal.concourt.sk/Zbierka/1999/25_99s.pdf)

Award of the Constitutional Court of the Slovak Republic file no. II. PL ÚS 43/95 of $10^{\text {th }}$ September 1996 published in the Collection of Laws under 281/1996 volume no. 95 (http://jaspi.justice.gov.sk/jaspiw1/htm_zak/jaspiw_mini_zak_zobraz_ clanok1.asp?kotva=k1\&skupina=1)

Award of the Constitutional Court of the Slovak Republic file no. I. ÚS 38/96 $17^{\text {th }}$ July 1996 published in the Collection of Awards under no. 42/96 (http://portal.concourt.sk/Zbierka/1996/42_96s.pdf)

Award of the Constitutional Court of the Slovak Republic file no. I. ÚS 59/00 of $20^{\text {th }}$ December 2001 published in the Collection of Awards under no. 57/01 (http://portal.concourt.sk/Zbierka/2001/57_01s.pdf)

Award of the Constitutional Court of the Slovak Republic file no. I. ÚS 49/01 of $19^{\text {th }}$ December 2001 published in the Collection of Awards under no. 56/01 (http://portal.concourt.sk/Zbierka/2001/56_01s.pdf)

Award of the Constitutional Court of the Slovak Republic file no. PL. ÚS 14/98 of $22^{\text {nd }}$ June 1999 published in the Collection of Laws under no. 166/1993, volume 73 (http://jaspi.justice.gov.sk/jaspiw1/htm_zak/jaspiw_mini_zak_zobraz_clanok1.asp?k otva $=\mathrm{k} 1$ \&skupina $=1$ )

Award of the Constitutional Court of the Slovak Republic file no. PL. ÚS 7/96 of $27^{\text {th }}$ February 1997, published in the Collection of Laws under no. 77/1997, volume no. 34 (http://jaspi.justice.gov.sk/jaspiw1/htm_zak/jaspiw_mini_zak_zobraz_clanok1. asp?kotva=k1\&skupina=1)

Award of the Constitutional Court of the Slovak Republic file no. II. ÚS 28/96 of $12^{\text {th }}$ May 1997 published in the Collection of Awards under no. 7/97 (http://portal.concourt.sk/Zbierka/1997/7_97s.pdf)

Award of the Constitutional Court of the Slovak Republic file no. II. ÚS 58/97 of $18^{\text {th }}$ February 1998 published in the Collection of Awards under no. 21/98 (http://portal.concourt.sk/Zbierka/1998/21_98s.pdf)

Award of the Constitutional Court of the Slovak Republic file no. II. ÚS 85/02 of $12^{\text {th }}$ March 2003 published in the Collection of Awards under no. 10/2003 (http://portal.concourt.sk/Zbierka/2003/10_03s.pdf)

Award of the Constitutional Court of the Slovak Republic file no. II. ÚS 40/97 of $8^{\text {th }}$ October 1997 published in the Collection of Awards under no. 17/97 (http://portal.concourt.sk/Zbierka/1997/17_97s.pdf) 
Award of the Constitutional Court of the Slovak Republic file no. II. ÚS 26/95 of $25^{\text {th }}$ October 1995 published in the Collection of Awards under no. 7/95 (http://portal.concourt.sk/Zbierka/1995/7_95s.pdf)

Award of the Constitutional Court of the Slovak Republic file no. PL. ÚS 43/95 of $10^{\text {th }}$ September 1996 published in the Collection of Awards under no. 281/1996, volume no. 95 (http://jaspi.justice.gov.sk/jaspiw1/htm_zak/jaspiw_mini_zak_zobraz_ clanok1.asp?kotva=k1\&skupina=1)

Award of the Constitutional Court of the Slovak Republic file no. IV. ÚS 1/02 of $26^{\text {th }}$ September 2002 published in the Collection of Awards under no. 85/02 (http://portal.concourt.sk/Zbierka/2002/85_02s.pdf)

Award of the Constitutional Court of the Slovak Republic file no. PL ÚS 25/01 of $7^{\text {th }}$ November 2002 published in the Collection of Laws under no. 620/2002, volume no. 243 (http://jaspi.justice.gov.sk/jaspiw1/htm_zak/jaspiw_mini_zak_zobraz_ clanok1.asp?kotva=k1\&skupina=1)

Award of the Constitutional Court of the Slovak Republic file no. ÚS 75/96 of $16^{\text {th }}$ April 1997 published in the Collection of Awards under no. 58/97 (http://portal.concourt.sk/Zbierka/1997/5_97s.pdf)

Judgment of the European Court of Human Rights in case of Dombo Beheer B.V. v. Netherlands of $27^{\text {th }} \quad$ October $1993 \quad$ (http://hudoc.echr.coe.int/sites/eng/ Pages/search.aspx\#\{"fulltext":["Dombo Beheer $\quad$ B.V. Netherlands"],"documentcollectionid2":["GRANDCHAMBER","CHAMBER"],"ite mid":["001-57850"]\})

Judgment of the European Court of Human Rights in case of Feldbrugge v. Netherlands of $29^{\text {th }} \quad$ May $1986 \quad$ (http://hudoc.echr.coe.int/sites/eng/Pages/ search.aspx\#\{"fulltext":["Feldbrugge"],"documentcollectionid2":["GRANDCHAM BER","CHAMBER"],"itemid":["001-57486"]\})

Judgment of the European Court of Human Rights in case of Luedicke, Belkacem and Koc v. Germany of $28^{\text {th }}$ November 1978 (http://hudoc.echr.coe.int/sites/eng/Pages/ search.aspx\#\{"fulltext":["Luedicke","Belkacem and Koc v. Germany"], "documentcollectionid2":["GRANDCHAMBER","CHAMBER"],"itemid":["001$57530 "]\})$

Judgment of the European Court of Human Rights in case of Mantovanelli v. France of $18^{\text {th }} \quad$ March $1997 \quad$ (http://hudoc.echr.coe.int/sites/eng/Pages/ search.aspx\#\{"fulltext":["Mantovanelli"],"documentcollectionid2":["GRANDCHA MBER","CHAMBER"],"itemid":["001-58023"]\})

Judgment of the Supreme Court of the Slovak Republic of $31^{\text {st }}$ August 1994, 5 Cdo 66/94 published under no. 31/1995

Resolution of the Constitutional Court of the Slovak Republic file no. I. ÚS 87/97 of $2^{\text {nd }}$ December 1997 published in the Collection of Awards under no. 56/97 (http://portal.concourt.sk/Zbierka/1997/56_97s.pdf)

Resolution of the Constitutional Court of the Slovak Republic file no. I. ÚS 64/97 of $8^{\text {th }}$ October 1997 published in the Collection of Awards no. 50/97 (http://portal.concourt.sk/Zbierka/1997/50_97s.pdf)

Resolution of the Supreme Court of the Slovak Republic of $26^{\text {th }}$ March 1992, 4 Cdo 6/92 


\section{Bibliography}

BAJCURA, A. \& coll.: Civil Procedural Law. Publishing unit of the Faculty of Law of the Comenius University, Bratislava 1995, p. 313

BOGUSZAK, J.: To the theory of law making (values, norms, legal principles). In: Faculty of Law UK 1348 - 1998 jubileum volume, Prague 1998, p. 326

BOGUSZAK, J.: Notion, kinds and importance of legal principles. In: Legal Horiozon no. 3/2003, p. 241-246

BUREŠ, J., DRÁPAL, L., MAZANEC, M.: Civil Procedural Order. Commentary, $2^{\text {nd }}$ edition, Prague, p. 1170

CAPEK, J.: European Court and European Commission for Human Rights. Linde, Prague 1995, p. 642

KÜHN, Z.: To the role of legal principles in the case law. In: SEP 5-6 2001, p. 62-69

MACUR, J.: Civil procedure and the principle of hearing. In: Bulletin of advocacy, 1/1997, p. 13-23

MACUR, J.: Evaluation of the pleadings of parties represented by lawyer in civil proceedings. In: Bulletin of advocacy 4/96, p. 4-10

MACUR, J.: Default judgment under $\S 114$ b of the CCP. In: Bulletin of Advocacy, 2/2002, p. 28-36

MACUR, J.: Judiciary and judicial law. University of J.E. Purkyne, Brno 1988, p. 154

MACUR, J.: Explanation duty of party not having the burden of proof in civil proceedings. In: Legal Horizon 5/2000, p. 200-204

MACUR, J.: The Importance of statements in compliance of both parties for ascertaining the facts of the case in civil proceedings. In: Legal Horizon 2/1997, p. 49-53

MACUR, J.: Interest of parties in explaining of the facts of the case in civil proceedings. In: Bulletin of advocacy, 2/1999, p. 10-21

MACUR, J.: Fundamental theoretical issues of legislative concept of civil proceedings. In: Bulletin of advocacy 9/1998, p. 6-17

MACUR, J.: Principle of hearing in civil proceedings. Masaryk University, Brno 1997, p. 233

MAZÁK, J.: Fundamental principles of civil procedural law. Iura Edition, Bratislava 2002, p. 638

NESROVNAL, V.: Problems of principle of material truth. In: Judicial revue, 55, 2003, no. 12, p. 1141-1143

PRUSÁK, J.: Principles in the law. In: Legal Horizon 3/1997, p. 221-227

PRUSÁK, J.: Theory of Law. VO PF UK, Bratislava 1995, p. 308

REPÍK, B.: Human rights in court proceedings. MANZ Bratislava, 1999, p. 256

RUBEŠ, J.: On some ethic principles of everyday work of judge and lawyer. In: Bulletin of advocacy, 11-12/2003, p. 19-30

SVÁK, J.: Selected principles of performance of judiciary. Concordia Trading, Bratislava 1996, p. 95

TELEC, I.: Legal principles and some other issues. In: Lawyer 6/2002, p. 621-633

VACULÍKOVÁ, N.: Application of law and legal principles. In: Legal Horizon 3/2003, p. $273-281$

WINTEROVÁ, A. \& coll.: Civil Procedural Law. Linde, Prague 1999, p. 663 
ZOULÍK, F.: Equality of parties and professionality of civil proceedings. In: Bulletin of advocacy $9 / 99$, p. 7-20

ZOULÍK, F.: Court and judiciary. C.H.BECK/SEVT, Prague 1995, p. 268

Collective of authors: Taking of evidence in civil and criminal proceedings, Judicial Academy, Pezinok 2012, p. 71

Selection of judgments of the European Court of Human Rights. Right to fair proceedings. Information Office of the Council of Europe, Bratislava 2001, p. 244 